\title{
Overview of Chaitén Volcano, Chile, and its 2008-2009 eruption
}

\author{
Jon J. Major ${ }^{1}$, Luis E. Lara ${ }^{2}$ \\ 1 United States Geological Survey, Cascades Volcano Observatory, 1300 SE Cardinal Court, Vancouver, Washington, 98683 , USA. \\ jjmajor@usgs.gov \\ 2 Servicio Nacional de Geología y Minería, Programa de Riesgo Volcánico, Avda. Santa María 0104, Santiago, Chile. \\ luis.lara@sernageomin.cl
}

\begin{abstract}
Chaitén Volcano erupted unexpectedly in May 2008 in one of the largest eruptions globally since the 1990 s. It was the largest rhyolite eruption since the great eruption of Katmai Volcano in 1912, and the first rhyolite eruption to have at least some of its aspects monitored. The eruption consisted of an approximately 2-week-long explosive phase that generated as much as $1 \mathrm{~km}^{3}$ bulk volume tephra $\left(\sim 0.3 \mathrm{~km}^{3}\right.$ dense rock equivalent) followed by an approximately 20-month-long effusive phase that erupted about $0.8 \mathrm{~km}^{3}$ of high-silica rhyolite lava that formed a new dome within the volcano's caldera. Prior to its eruption, little was known about the eruptive history of the volcano or the hazards it posed to society. This edition of Andean Geology contains a selection of papers that discuss new insights on the eruptive history of Chaitén Volcano, and the broad impacts of and new insights obtained from analyses of the 2008-2009 eruption. Here, we summarize the geographic, tectonic, and climatic setting of Chaitén Volcano and the pre-2008 state of knowledge of its eruptive history to provide context for the papers in this edition, and we provide a revised chronology of the 2008-2009 eruption.
\end{abstract}

Keywords: Chaitén Volcano, Rhyolite, Explosive eruption, Ash fall, Lava dome, Pyroclastic density current, Lahar, Environmental impact, Ecological disturbance, Holocene stratigraphy, Geophysical monitoring.

RESUMEN. Revisión del volcán Chaitén y su erupción 2008-2009. Chile. El volcán Chaitén entró en erupción inesperadamente en mayo de 2008 generando una de las mayores erupciones globales desde la década de 1990. Esta fue la mayor erupción riolítica desde la gran erupción del volcán Katmai en 1912 y la primera de este tipo en que al menos algunas de sus fases fueron instrumentalmente monitoreadas. La erupción consistió en una fase explosiva de aproximadamente 2 semanas de duración que generó un volumen de $1 \mathrm{~km}^{3}$ de tefra $\left(\sim 0,3 \mathrm{~km}^{3}\right.$ equivalente roca densa), seguida por una fase efusiva de aproximadamente 20 meses de duración que evacuó alrededor de $0,8 \mathrm{~km}^{3}$ de lava riolítica de alto contenido de sílice, lo que formó un nuevo domo dentro de la caldera del volcán. Hasta el inicio de este evento, se sabía poco sobre la historia eruptiva del volcán o los peligros que este imponía a la sociedad. Esta edición de Andean Geology contiene una selección de artículos que ofrecen nuevas perspectivas sobre la historia eruptiva del volcán Chaitén y el amplio espectro de nuevos conocimientos obtenidos del estudio de la erupción de 2008-2009. Aquí resumimos la configuración geográfica, tectónica y climática de este volcán y el estado del conocimiento previo para proporcionar un contexto a los artículos de esta edición, junto con una cronología revisada de la erupción de 2008-2009.

Palabras clave: Volcán Chaitén, Riolitas, Erupción explosiva, Caída de cenizas, Domo de lava, Flujos pirocláticos, Lahares, Impacto ambiental, Perturbación ecológica, Estratigrafía del Holoceno, Monitoreo geofísico. 


\section{Introduction}

Chaitén Volcano, located near $42.8^{\circ} \mathrm{S}$ in southern Chile, is a relatively small, remote rhyolitic volcano that sits about $17 \mathrm{~km}$ west-southwest of the much larger and heavily glaciated Michinmahuida Volcano (2,400 m elevation). It consists of a 3-km-wide caldera that, before 2008, contained an approximately $0.5 \mathrm{~km}^{3}$ lithic-and-obsidian rhyolite lava dome. In contrast to the abundance of repetitive eruptive activity of many other volcanoes in southern Chile (Dzierma and Wehrmann, 2012), Chaitén was perceived as being inactive, although it was thought to have erupted in the early Holocene, about 9,400 yBP (Naranjo and Stern, 2004). Owing to its apparent lack of activity, and despite its proximity to the important port town of Chaitén (Stern et al., 2007), the volcano was not considered to be a significant threat and was not actively monitored. Prior to 2008, the nearest seismic station was located approximately $300 \mathrm{~km}$ north. Perceptions of Chaitén, and the threat it poses to society, changed when the volcano erupted unexpectedly and explosively in May 2008 in one of the largest eruptions worldwide since the early 1990s. That eruption of crystal-poor, high-silica rhyolite (73-76 wt $\% \mathrm{SiO}_{2}$; Castro and Dingwell, 2009) produced one of the few rhyolite eruptions since the early 1900s, and the largest since the great eruption of Katmai Volcano, Alaska, in 1912 (Hildreth and Fierstein, 2012). Even though the region surrounding the volcano is sparsely populated, the eruption wreaked considerable havoc. The violent eruption, having a volcanic explosivity index value (VEI; Newhall and Self, 1982) of 4-5 (Carn et al., 2009), ejected tephra to altitudes of $18-20 \mathrm{~km}$, and winds widely dispersed that tephra eastward across Argentina and out to the South Atlantic Ocean (Carn et al., 2009; Watt et al., 2009; Durant et al., 2012). Distal tephra dispersal upset commercial airline traffic and disrupted daily life in downwind communities (Wilson et al., 2009a, b). Flooding and sediment transport associated with erosion of tephra by subsequent rainfall severely damaged the small port town of Chaitén (population $~ 4,600$ ) located $10 \mathrm{~km}$ south of the volcano (Pierson et al., 2013), loaded regional rivers with large amounts of sediment, and disrupted local aquaculture, tourism, and other economic endeavors. Following a shortlived explosive phase, the eruption transitioned to a prolonged effusive phase that lasted through 2009.
This edition of Andean Geology includes nine papers discussing various aspects of the 2008-2009 eruption of Chaitén Volcano and its Holocene eruptive activity. To provide context for these papers, we briefly summarize the geographic, geologic, physiographic, climatic, and tectonic settings of Chaitén, provide a revised chronology of the eruption, and broadly summarize its impacts. The impetus for this edition came about during a period of concentrated, intensive field work at Chaitén in January and February 2010 by an interdisciplinary team of international scientists (Pallister et al., 2010). That field work drew together geologists, hydrologists, and ecologists to examine the impacts and products of the 2008-2009 eruption. Several papers in this volume represent studies initiated or advanced during that field campaign.

\subsection{Geographic, geologic, physiographic, and climatic setting}

The volcanic arc of South America, which includes over 200 potentially active Quaternary volcanoes and 12 caldera systems, spans the length of the western margin of the continent (Stern, 2004; Siebert et al., 2010). Subduction of the Nazca and Antarctic plates obliquely beneath the South American plate fuels this volcanic arc, but also segregates it into four distinct segments separated by volcanically inactive gaps (Stern, 2004). These segments are the Northern (NVZ; $\left.5^{\circ} \mathrm{N}-2^{\circ} \mathrm{S}\right)$, Central (CVZ; $\left.14^{\circ}-27^{\circ} \mathrm{S}\right)$, Southern (SVZ; $33^{\circ}-46^{\circ} \mathrm{S}$ ), and Austral Volcanic Zones (AVZ; $49^{\circ}-55^{\circ} \mathrm{S}$ ), respectively. Below the NVZ, CVZ, and SVZ the Nazca plate is subducting rapidly at rates as great as $70-90 \mathrm{~mm} / \mathrm{y}$, and it dips beneath the continental plate at angles between $20^{\circ}$ and $30^{\circ}$; in contrast, it slips in a nearly flat manner in the volcanic gaps (Stern, 2004). Unlike the subduction of the Nazca plate, the Antarctic plate subducts slowly $(\sim 20 \mathrm{~mm} / \mathrm{yr})$ beneath the AVZ. Although there is apparently no Benioff zone of seismicity that defines the subducting plate (Stern, 2004), Cande and Leslie (1986) infer that the Antarctic plate likely dips beneath the South American plate at an angle similar to that of the Nazca plate, about $20^{\circ}$ in southernmost Chile. Aside from a few volcanoes in the Antarctic peninsula and a few intraplate volcanic fields, the volcanoes of Chile lie mainly within the CVZ, SVZ, and AVZ (Fig. 1). About 95 of these volcanic centers are considered to be geologically active and hence 


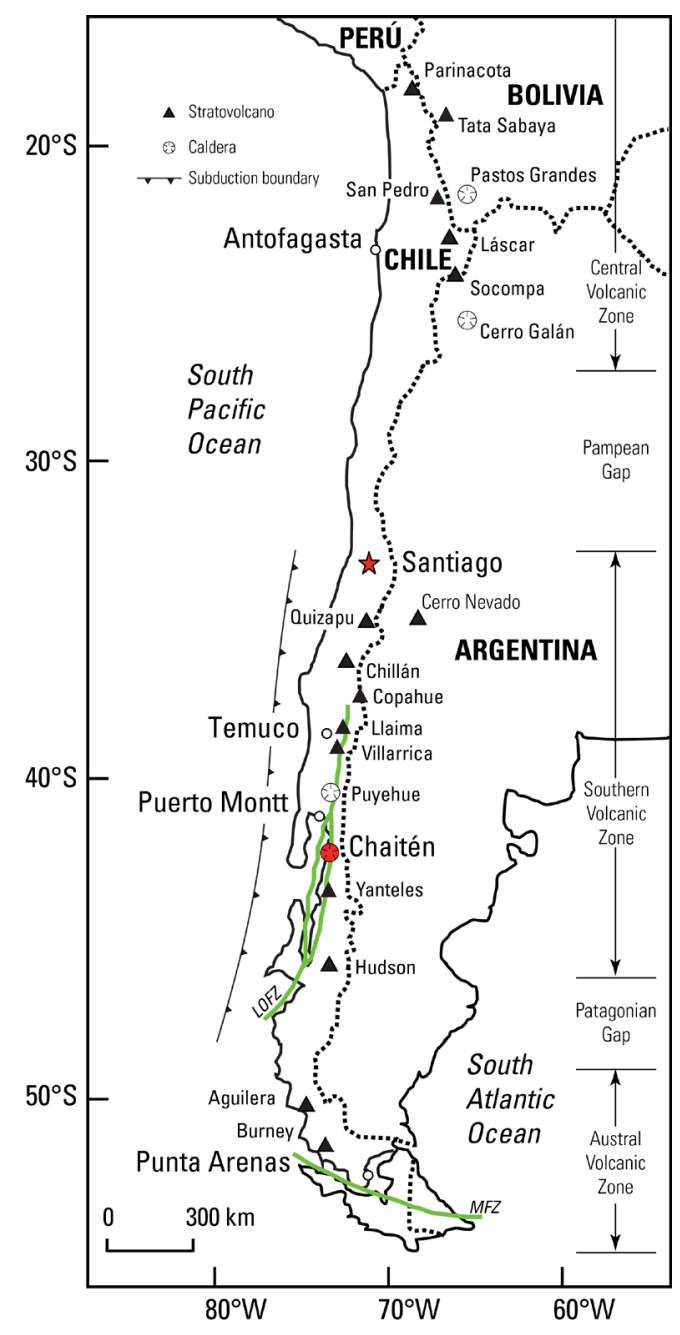

FIG. 1. Regional schematic map showing location of the South American Central Volcanic Zone (CVZ), Southern Volcanic Zone (SVZ), Austral Volcanic Zone (AVZ), and intervening volcanic gaps. A few major volcanoes and calderas are shown. Chaitén Volcano is a small caldera volcano located near the southern end of the SVZ. Approximate location of the Nazca-South American plate boundary is shown. LOFZ is the Liquiñe-Ofqui fault zone; MFZ is the Magallanes fault zone. For greater detail, see López-Escobar et al. (1993), Stern (2004), Wang et al. (2007), and Cembrano and Lara (2009).

pose potential threats to society (Stern et al., 2007; Lara et al., 2011a).

The most recently active volcanoes of Chile are located in the SVZ (López-Escobar et al., 1993; Stern, 2004; Cembrano and Lara, 2009; Siebert et al., 2010). The SVZ is an 80 - to $200-\mathrm{km}$-wide arc segment that includes at least 60 historically and potentially active volcanoes in Chile and Argentina as well as 3 silicic caldera systems that are less than 1.1 Ma (Stern, 2004; Stern et al., 2007). Volcanoes in the northern and central parts of the SVZ generally overlie Miocene to Pliocene volcanic rocks, whereas in the southern part of the SVZ they typically overlie Paleozoic metamorphic rocks, Mesozoic and Cenozoic plutons, and Miocene to Pliocene volcanic rocks. Chaitén Volcano lies near the southern end of the SVZ (Fig. 1). It overlies basement rock composed mainly of granodiorite and greenschist (SERNAGEOMIN, 2002; Piña-Gauthier et al., 2013, this volume).

Crustal thickness beneath the SVZ decreases southward (Stern, 2004; Cembrano and Lara, 2009, and references therein). At the northern end of the SVZ, the crust is about $50 \mathrm{~km}$ thick, and its thickness decreases steadily to $30 \mathrm{~km}$ or less in the southern end (Stern, 2004; Cembrano and Lara, 2009). Volcanoes in the SVZ predominantly erupt basalt and basaltic andesite (López-Escobar et al., 1993), although centers have erupted andesite, dacite, and rhyolite. Chaitén is the only volcano in the southern part of the SVZ known to have erupted a large-volume of rhyolite (López-Escobar et al., 1993). Puyehue Volcano, a small caldera located in the more central part of the SVZ north of Puerto Montt (Fig. 1) has also erupted rhyolite, and Yate Volcano, $140 \mathrm{~km}$ north of Chaitén, may have erupted rhyolite once during the Holocene (Watt et al., 2009).

Chaitén Volcano, at 1,122 m elevation, sits atop a high-relief $(600-800 \mathrm{~m})$ ridge about $10 \mathrm{~km}$ inland from the Gulf of Corcovado (Fig. 2). The volcano is surrounded by steep, dissected, high-relief, volcanic and glaciated terrain that is densely covered in temperate rainforest vegetation. Two principal river systems drain the volcano: the Rayas River to the north and the Chaitén River to the south. Channels on the east flank of the volcano drain into the Rayas River through an unnamed tributary channel informally referred to in this edition as East River, which originates on Michinmahuida Volcano. A prominent channel originating at the lowest point on the eastern caldera rim, informally referred to in this edition as East Breach Creek, dissects the east flank and drains into East River (Fig. 2). One tributary of the Chaitén River, informally referred to as Caldera Creek, drains the caldera through a breach in the south rim (Fig. 2). The coastal town of Chaitén sits on a broad plain $10 \mathrm{~km}$ south of the volcano near the mouth of Chaitén River. 


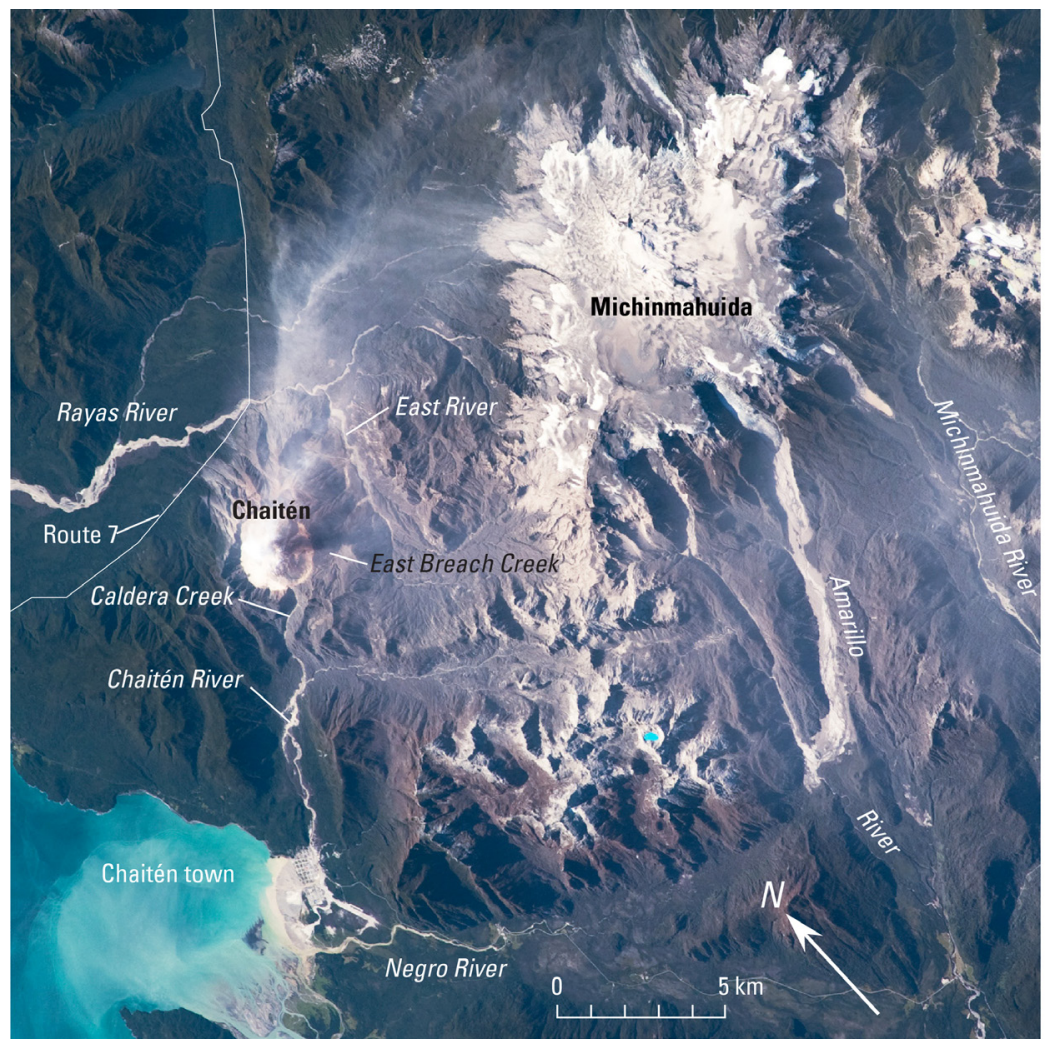

FIG. 2. Photograph showing light-colored Chaitén lava dome, the volcano's major drainage channels, and the larger and glaciated Michinmahuida Volcano. The small port town of Chaitén is located about $10 \mathrm{~km}$ south of Chaitén Volcano. Route 7, the major land link north of the volcano, passes within $2 \mathrm{~km}$ of the caldera rim. Note the minor ash plume drifting northeast of the volcano, the heavily damaged forest east to southeast of the volcano, and the plume of sediment entering Chaitén Bay. International Space Station image ISS018-E-035716 taken 24 February 2009. Image provided by NASA's Image Science and Analysis Laboratory, Johnson Space Center.

The southern end of the SVZ west of the Andean crest is dominated by the generally wet climate of the Andean Patagonia region (Garreaud et al., 2013). Moisture-laden airflow from the southern Pacific Ocean delivers prolonged, and sometimes intense, rainfall to northern Patagonia $\left(40^{\circ}-48^{\circ} \mathrm{S}\right)$. Frontal storms, driven mainly by westerly winds (Smith and Evans, 2007), traverse low-relief offshore islands and locally narrow coastal plains before encountering and ascending 1- to 2-km-high mountain ridges. Orographic precipitation increases with altitude by a factor of about 2-3 from the coast to the western front of the Andes (Garreaud, 2009); annual mean precipitation in western Patagonia ranges from about 5,000-10,000 $\mathrm{mm}$ (Garreaud et al., 2013), and exceeds $6,000 \mathrm{~mm}$ just west of the continental divide at $45^{\circ} \mathrm{S}$ (Garreaud, 2009), which has a mean altitude of about 1,500 m a.s.l. (Smith and Evans, 2007). Precipitation in the broad region around Chaitén Volcano varied from about 2,500 to 7,000 $\mathrm{mm}$ from 2004-2009 (Pierson et al., 2013; Dirección General de Aguas, unpublished data ${ }^{1}$; Fundación Huinay, unpublished data²).

The temperate rainforest of the southern Chilean coast near Chaitén is characteristic of the cool, wet climate (Alaback, 1991). Forest vegetation is dominated by dense stands of Nothofagus dombeyi, Nothofagus nitida, Weinmannia, Aextoxicon, Laurelia, Drimys, Podocarpus, and Eucryphia cordifolia (also see Swanson et al., 2013, this volume). Epiphytes, such as lianas, are commonly hosted by these trees. The understory is dominated by impenetrable thickets of Chusquea bamboo along with other understory tree and woody shrub species. Catastrophic disturbance, whether caused by fire, landslides, volcanism, or severe winds is an important component of stand structure in this forest (Alaback, 1991). 


\subsection{Tectonic influences on the Southern Volcanic Zone of the Chilean Andes}

The tectonic setting of the SVZ is characterized by oblique convergence between the Nazca and South American plates at rates ranging from $\sim 18$ $66 \mathrm{~mm} / \mathrm{y}$ (Wang et al., 2007; Cembrano and Lara, 2009). The upper crust in the northern segment of the SVZ is characterized by margin-parallel folds and thrusts of Cenozoic age. In the southern segment of the SVZ, exhumation has exposed the orogenic roots of the Andes. Owing to the complex interplay among stress regimes and inherited structures, parts of the SVZ are undergoing compression, local extension, or transpression (combined translation and compression). A major, 1,200-km-long intra-arc fault system, the Liquiñe-Ofqui fault zone (LOFZ; Fig. 1), dominates the SVZ between $38^{\circ}$ and $47^{\circ} \mathrm{S}$ (Wang et al., 2007; Cembrano and Lara, 2009). The LOFZ is a transpressional, right-lateral strike-slip zone up to $100 \mathrm{~km}$ wide which has been active for at least the last 6 m.y., and geologic evidence suggests it may have been active as long ago as $25 \mathrm{Ma}$ (Cembrano and Lara, 2009). It runs near or under many of the volcanoes in the central and southern parts of the SVZ (Fig. 1). The margin-parallel slip rate between the Nazca and South American plates ranges from about 23-28 mm/y (Wang et al. 2007, 2008 , and references therein). In contrast, the strikeslip component of motion along the LOFZ is much less. Geodetic measurements since the mid-1990s show that between $42^{\circ} \mathrm{S}$ and $44^{\circ} \mathrm{S}$ the LOFZ slips at an average rate of $6.5 \mathrm{~mm} / \mathrm{yr}$ (Wang et al., 2007). This rate is about $30 \%$ of the relative margin-parallel motion between the plates.

Complex feedbacks between tectonics and volcanism in the SVZ control the style and distribution of volcanism in southern Chile. First-order, long-term controls are related to crustal thickness, the structure of the lithosphere, and the presence of an intra-arc fault system (Cembrano and Lara, 2009). The relatively thicker crust in the northern SVZ favors magma differentiation, whereas the relatively thin crust and the presence of the LOFZ in the central and southern SVZ provide multiple pathways for magma migration that may or may not favor crustal residence and magma differentiation (Cembrano and Lara, 2009). Cembrano and Lara (2009) propose two main types of volcano-tectonic interactions to account for the various spatial organizations of volcanoes observed along the SVZ: 1. a kinematically coupled association in which the spatial and temporal distribution of volcanism is related to second-order structures, such as tension cracks, shear fractures, and fissures, caused by the overall transpressional kinematics of the volcanic arc; and 2. a kinematically uncoupled association in which the spatial and temporal distribution of volcanism has no direct relation to the prevailing intra-arc stress field, but is instead related to inherited lithospheric structures that may provide pathways for magma migration. The presence of flank cones on many of the major stratovolcanoes, most of them forming NE-trending alignments that parallel the maximum horizontal stress (e.g., Lara et al. 2011b), as well as geophysical data obtained during some eruptions (Barrientos and Acevedo, 1992) show that arc tectonics and inherited structures clearly influence patterns of volcanism in the Southern Andes.

Chaitén Volcano, situated near the southern end of the SVZ, lies along a forearc sliver between the Chilean subduction zone and the LOFZ (Fig. 1; Wang et al., 2007; Wicks et al., 2011). It is located approximately in the middle of, but inland from, the zone ruptured during the $\mathrm{M}_{\mathrm{w}} 9.5$ great Chilean earthquake of 1960 (Wang et al., 2007). Deformation modeling by Wicks et al. (2011) suggests that the 2008-2009 eruption of Chaitén was fueled by magma that resides along an east-northeast dipping reverse fault related to the LOFZ (also see Piña-Gauthier $e t$ al., 2013, this volume).

\subsection{Pre-2008 state of knowledge of eruptive his- tory of Chaitén Volcano}

Prior to the 2008-2009 eruption, very little was known of the eruptive history of Chaitén Volcano. Naranjo and Stern (2004) examined a number of outcrops along road cuts on both the Chilean and Argentinean sides of the Andes between $42.5^{\circ}$ to $45^{\circ} \mathrm{S}$, and identified evidence for four small $(\mathrm{VEI}<3)$ and seven moderate to large (VEI $=3-5)$ Holocene eruptions from seven of the stratovolcanoes in the southern part of the SVZ. Only one of those eruptions was correlated to Chaitén. Outcrops north of the volcano expose pyroclastic density current (PDC) and tephra fall deposits. Fragments of charcoal from within the PDC deposit had a radiocarbon age of 9,370 yBP and a tree trunk underlying it had a radiocarbon age of 9,810 yBP. The fall deposit overlying the PDC deposit consists of white to yellow rhyolite pumice 
capped by a thin layer of mafic scoria. There is no soil developed between the PDC and fall deposits. On the basis of the obtained dates, deposit compositions, and the lack of soil development between the PDC and fall deposits, Naranjo and Stern (2004) inferred that the PDC and rhyolite pumice fall are products of a single eruption that perhaps created the summit caldera about 9,400 yBP. A 'thick tephra layer' exposed in a road cut $4 \mathrm{~km}$ north of the town of Chaitén and west of the volcano dated at $<10,260$ yBP and a tephra layer in another outcrop near the mouth of the Rayas River (Fig. 2) dated at $<9,580$ yBP may be from the same explosive event (Naranjo and Stern, 2004). The age of the intracaldera dome is uncertain but older than $5,600 \mathrm{yBP}$, because obsidian cobbles from the dome fashioned into artifacts have been found in archeological sites of that age as far as $300 \mathrm{~km}$ distant along the Pacific coast (Stern et al., 2002), and some even as far as $1,200 \mathrm{~km}$ distant along the Atlantic coast of Argentina (Stern et al., 2012).

Naranjo and Stern (2004) did not recognize downwind tephra fall deposits from Chaitén east of the volcano. However, deposits of rhyolite pumice dated between 3,820 and 1,840 yBP were found in Argentina near the city of Esquel and along the shores of Futalafquén Lake, 80-100 km downwind from Chaitén (Naranjo and Stern, 2004). These deposits, geochemically similar to the Chaitén rhyolite pumice, were attributed instead to an eruption of Michinmahuida Volcano, even though Michinmahuida is not known to have erupted rhyolite, because the dispersal pattern of that tephra fall matched the dispersal pattern of another tephra fall from Michinmahuida. All other tephras found in the region were of basalt to dacite composition, and not related to eruptions of Chaitén. On the basis of the outcrops they observed and sampled, Naranjo and Stern (2004) concluded that the last major eruption of Chaitén occurred about 9,400 yBP. No historical accounts of eruptions of Chaitén were known about at the time of their study.

\section{Chronology of the 2008-2009 eruption}

Owing to the perceived lack of eruptive activity of Chaitén during the Holocene, the volcano was not considered to be a significant threat despite its close proximity to the town of Chaitén, and thus was not actively monitored. As a result, when it erupted in 2008, it appeared to have reawakened with little precursory unrest. Lack of detection of precursory activity may be largely a function of a lack of instrumentation on or near the volcano. However, there is evidence that unrest escalated rapidly to eruption. Residents of the town of Chaitén felt earthquakes only 24 hours before the eruption produced ashfall, and petrological evidence suggests that the rhyolite magma that fueled the eruption ascended rapidly from depths of 5-9 $\mathrm{km}$ in as little as 4 hours (Castro and Dingwell, 2009). Analysis of Interferometric Synthetic Aperture Radar (InSAR) images suggests this rapid ascent of magma occurred through dike propagation from an inclined sill that originates beneath Michinmahuida Volcano (Wicks et al., 2011).

Once the eruption began, it went through a brief ( $\sim 2$ week) but energetic explosive phase and then entered a prolonged ( $\sim 18-20$ month) effusive phase (Pallister et al., 2013, this volume). We highlight the key chronology of the eruption (Table 1).

\subsection{Explosive phase}

The eruption of Chaitén Volcano began late on 1 May 2008 (local time) with minor emissions of ash (Table 1). A M3.5 earthquake located approximately $15 \mathrm{~km}$ north of Chaitén town was detected instrumentally a few hours before ash was observed falling in town. The eruption then escalated rapidly; the first Plinian eruption began on 2 May at $\sim 03: 30$ UTC (local time $=$ UTC-4 hrs) and was confirmed a few hours later by visual observations. That eruption lofted an ash column to an altitude of more than $20 \mathrm{~km}$ (Carn et al., 2009). By approximately 16:00 UTC, PDCs were observed on the north and northeast flanks. An overflight on 3 May revealed that two vents had opened on the north-northwest side of the lava dome (SERNAGEOMIN, 2008a) ${ }^{3}$. The early tephra plumes were dispersed broadly downwind across Argentina and out to the South Atlantic Ocean (Fig. 3a; Watt et al., 2009; Osores et al. 2013, this volume). Explosive activity waned slightly over the next few days, but maintained sustained eruption columns achieving heights of $<10-12 \mathrm{~km}$. On 6 May, the intensity of explosive activity increased sharply leading to a climactic explosion (Fig. 3b) that lofted an eruption column to at least $18-20 \mathrm{~km}$ altitude (Folch et al., 2008; Carn et al., 2009; Durant et al., 2012). During the day, explosive activity waxed and waned. By that time, the town of Chaitén had been fully evacuated. On 7 May, explosive activity again waned, with sustained eruption columns achieving 
TABLE 1. ERUPTION CHRONOLOGY FOR THE 2008-2009 ERUPTION OF CHAITÉN VOLCANO, CHILE (MODIFED FROM DURANT ET AL., 2012).

\begin{tabular}{|c|c|c|c|c|c|}
\hline Date & Time (UTC)* & Observation & Cloud height & $\begin{array}{c}\text { Measurement } \\
\text { source }\end{array}$ & Reference \\
\hline \multirow[t]{2}{*}{1 May 2008} & $\sim 00: 00-1: 00$ & $\begin{array}{l}\text { Residents of Chaitén town feel } \\
\text { earthquakes. SERNAGEOMIN } \\
\text { detects volcano-tectonic (VT) } \\
\text { earthquakes thought to be loca- } \\
\text { ted in Chaitén region; } 15 \text { major } \\
\text { earthquakes detected over next } \\
30 \text { hours }\end{array}$ & t & $\begin{array}{l}\text { Eyewitness reports; } \\
\text { seismic detection }\end{array}$ & $\begin{array}{l}\text { Basualto et al. (2008); } \\
\text { Castro and Dingwell (2009); } \\
\text { SERNAGEOMIN (2008a) }\end{array}$ \\
\hline & $19: 58$ & $\begin{array}{l}\text { Instrumentally detected earth- } \\
\text { quake that may signal onset of } \\
\text { eruption; } \sim \mathrm{M} 3.5 \text {, location } \sim 15 \\
\text { km north of Chaitén town. } * *\end{array}$ & 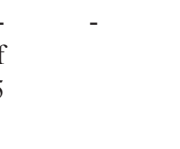 & Seismic detection & Basualto et al. (2008) \\
\hline \multirow[t]{8}{*}{2 May 2008} & 01:00 & $\begin{array}{l}\text { Minor ash fall observed in Chai- } \\
\text { tén town }\end{array}$ & - & Eyewitness reports & Castro and Dingwell (2009) \\
\hline & 03:38 & $\begin{array}{l}\text { Seismicity suggests onset of vio- } \\
\text { lent eruption thought to perhaps } \\
\text { be from Michinmahuida Volcano }\end{array}$ & 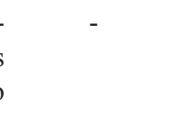 & Seismic detection & SERNAGEOMIN (2008a) ${ }^{3}$ \\
\hline & $06: 35$ & $\begin{array}{l}\text { SERNAGEOMIN receives re- } \\
\text { ports of ashfall in Chaitén town }\end{array}$ & - & Eyewitness reports & SERNAGEOMIN $(2008 \mathrm{a})^{3}$ \\
\hline & 08:00-14:00 & Explosive Plinian ash column & $>20 \mathrm{~km}$ & $\begin{array}{l}\text { Visual observations } \\
\text { (PIREP) }\end{array}$ & $\begin{array}{l}\text { Folch et al. (2008); Carn et } \\
\text { al. (2009) }\end{array}$ \\
\hline & Morning & $\begin{array}{l}\text { Dual vents through existing lava } \\
\text { dome }\end{array}$ & - & Visual observation & SERNAGEOMIN (2008a) ${ }^{3}$ \\
\hline & & Early column activity & $11-17 \mathrm{~km}$ & $\begin{array}{l}\text { Visual observations } \\
\text { (SGVP) }\end{array}$ & Folch et al. (2008) \\
\hline & & Stratospheric cloud height & $12 \mathrm{~km}$ & GOES imagery & Carn et al. (2009) \\
\hline & $\sim 16: 00$ & $\begin{array}{l}\text { Pyroclastic density currents on } \mathrm{N} \\
\text { and NE flanks }\end{array}$ & & $\begin{array}{l}\text { Visual observations } \\
\text { (PIREP) }\end{array}$ & Aerotaxis del Sur \\
\hline \multirow[t]{2}{*}{3 May 2008} & & $\begin{array}{l}\text { Deployment of seismic network } \\
\text { around Chaitén }\end{array}$ & - & - & Basualto et al. (2008) \\
\hline & $18: 15$ & Explosive ash column & $17-20 \mathrm{~km}$ & $\begin{array}{l}\text { Visual observation } \\
\text { (clinometer) }\end{array}$ & G. Villarosa \\
\hline 3-4 May 2008 & & Fine volcanic ash emission & $\sim 12 \mathrm{~km}\left(30^{\circ} \mathrm{S}\right)$ & CALIOP/OMI & Carn et al. (2009) \\
\hline 3-5 May 2008 & & $\begin{array}{l}\text { Sustained explosive ash emis- } \\
\text { sions }\end{array}$ & $<10 \mathrm{~km}$ & $\begin{array}{l}\text { MODIS/visual } \\
\text { observations }\end{array}$ & Watt et al. (2009) \\
\hline 4-12 May 2008 & & $\begin{array}{l}\sim 70 \mathrm{VT} \text { events per day; avera- } \\
\text { ge maximum M3.5; strongest at } \\
5-18 \mathrm{~km} \text { depth }\end{array}$ & t & Seismic detection & Basualto et al. (2008) \\
\hline \multirow[t]{3}{*}{6 May 2008} & $12: 00 * * *$ & Explosive ash column & $30 \mathrm{~km}^{* * *}$ & $\begin{array}{l}\text { Visual observation } \\
\text { estimate }\end{array}$ & Carn et al. (2009) \\
\hline & $13: 30 * * *$ & Explosive ash column & $30 \mathrm{~km} * * *$ & $\begin{array}{l}\text { Visual observation } \\
\text { (ONEMI) }\end{array}$ & Folch et al. (2008) \\
\hline & 20:00 & Increase in eruption intensity & - & Visual observation & Folch et al. (2008) \\
\hline \multirow[t]{2}{*}{7 May 2008} & & Eruption column & $7-10 \mathrm{~km}$ & CALIOP & Folch et al. (2008) \\
\hline & $20: 00-21: 35$ & Eruption column & $10-20 \mathrm{~km}$ & Visual observations & SERNAGEOMIN $(2008 \mathrm{~b})^{4}$ \\
\hline
\end{tabular}


Table 1 continued.

\begin{tabular}{|c|c|c|c|c|c|}
\hline Date & Time (UTC)* & Observation & Cloud height & $\begin{array}{l}\text { Measurement } \\
\text { source }\end{array}$ & Reference \\
\hline \multirow[t]{4}{*}{8 May 2008} & $03: 30$ & Explosive ash eruption & $20-22 \mathrm{~km}$ & GOES imagery & Carn et al. (2009) \\
\hline & $11: 15-19: 15$ & $\begin{array}{l}\text { Small pyroclastic density cur- } \\
\text { rents east of volcano }\end{array}$ & - & Visual observations & SERNAGEOMIN $(2008 \mathrm{c})^{5}$ \\
\hline & & Ash/mixed ice-ash cloud & $\begin{array}{c}\sim 16 \mathrm{~km} \\
\left(41-42^{\circ} \mathrm{S}\right)\end{array}$ & CALIOP & Thomason and Pitts (2008) \\
\hline & & $\begin{array}{l}\text { Seismicity declines abruptly to } \\
\sim 20 \text { VT events per day; average } \\
\text { maximum } \sim \mathrm{M} 3\end{array}$ & - & Seismic detection & Basualto et al. (2008) \\
\hline 8-12 May 2008 & & $\begin{array}{l}\text { Hybrid earthquakes and long- } \\
\text { period low-frequency (LP) } \\
\text { earthquakes detected in addition } \\
\text { to VT quakes. Hindsight analysis } \\
\text { suggests this may signal onset } \\
\text { of effusion of lava from merged } \\
\text { vents in the old lava dome. }\end{array}$ & - & Seismic detection & Basualto et al. (2008) \\
\hline \multirow[t]{3}{*}{9 May 2008} & & Volcanic aerosol & $13 \mathrm{~km}$ & CALIOP & Carn et al. (2009) \\
\hline & $16: 00-20: 00$ & $\begin{array}{l}\text { Small pyroclastic density cur- } \\
\text { rents east of volcano }\end{array}$ & & Visual observations & SERNAGEOMIN $(2008 \mathrm{~d})^{6}$ \\
\hline & $16: 00-20: 00$ & Explosive ash cloud & $\sim 8$ & Visual observations & SERNAGEOMIN $(2008 \mathrm{~d})^{6}$ \\
\hline \multirow[t]{2}{*}{12 May 2008} & $19: 00$ & Chaitén town observed flooded & & Visual observations & SERNAGEOMIN $(2008 \mathrm{e})^{7}$ \\
\hline & & $\begin{array}{l}\text { Explosive activity wanes-cloud } \\
\text { height diminished }\end{array}$ & $\begin{array}{l}\sim 4.5 \mathrm{~km} \\
\text { sustained }\end{array}$ & Visual observations & SERNAGEOMIN $(2008 \mathrm{e})^{7}$ \\
\hline 21 May 2008 & & $\begin{array}{l}\text { Newly effusing lava observed on } \\
\text { north side of old lava dome. }\end{array}$ & - & Visual observations & SERNAGEOMIN (2008f) ${ }^{8}$ \\
\hline $\begin{array}{l}\text { June-September } \\
2008\end{array}$ & & Exogenous dome growth & - & $\begin{array}{l}\text { Visual/satellite } \\
\text { observations }\end{array}$ & $\begin{array}{l}\text { Pallister et al. } 2013 \text {, this } \\
\text { volume) }\end{array}$ \\
\hline $\begin{array}{l}\text { June-November } \\
2008\end{array}$ & & $\begin{array}{l}\text { Minor dome collapses and py- } \\
\text { roclastic flows within caldera; } \\
\text { one substantial dome collapse } \\
\text { and pyroclastic flow into Chaitén } \\
\text { River valley }\end{array}$ & - & $\begin{array}{l}\text { Visual/satellite } \\
\text { observations }\end{array}$ & $\begin{array}{l}\text { Major et al. }(2013, \text { this } \\
\text { volume) }\end{array}$ \\
\hline $\begin{array}{l}\text { October } 2008- \\
\text { February } 2009\end{array}$ & & $\begin{array}{l}\text { Spine extrusion and endogenous } \\
\text { dome growth }\end{array}$ & - & $\begin{array}{l}\text { Visual/satellite } \\
\text { observations }\end{array}$ & $\begin{array}{l}\text { Pallister et al. }(2013, \text { this } \\
\text { volume }) \text { B Bernstein et al. } \\
(2013, \text { this volume })\end{array}$ \\
\hline $\begin{array}{l}19 \text { February } \\
2009\end{array}$ & $14: 40$ & $\begin{array}{l}\text { Large dome collapse and pyro- } \\
\text { clastic flow down Chaitén River } \\
\text { valley }\end{array}$ & - & Visual observations & $\begin{array}{l}\text { Dagoberto Guzman; Major } \\
\text { et al. }(2013, \text { this volume })\end{array}$ \\
\hline $\begin{array}{l}\text { March } 2009 \text { - } \\
\text { January 2010(?) }\end{array}$ & & $\begin{array}{l}\text { Endogenous dome growth. } \\
\text { Growth ceases by late } 2009 \text { to } \\
\text { early } 2010 \text {. }\end{array}$ & - & $\begin{array}{l}\text { Visual/satellite } \\
\text { observations }\end{array}$ & $\begin{array}{l}\text { Pallister et al. }(2013 \text {, this } \\
\text { volume) }\end{array}$ \\
\hline
\end{tabular}

CALIOP Cloud-Aerosol Lidar with Orthogonal Polarisation (on Cloud-Aerosol Lidar and Infrared Pathfinder Satellite Observation platform).

GOES Geostationary Operational Environmental Satellite.

OMI Ozone Monitoring Instrument.

ONEMI Oficina Nacional de Emergencia del Ministerio del Interior.

SGVP Smithsonian Global Volcanism Program.

* Chilean local time is UTC-4 hrs.

** $\quad$ Nearest seismometer was located about $300 \mathrm{~km}$ distant.

*** These reports conflict on the time of onset of the initial explosive ash column. Reanalysis indicates column height reached only to about $20 \mathrm{~km}$ altitude.

\footnotetext{
5 SERNAGEOMIN. 2008c. Erupción del volcán Chaitén, Cuarto Informe Técnico, 08 de Mayo de 2008: 4 p.

6 SERNAGEOMIN. 2008d. Erupción del volcán Chaitén, Quinto Informe Técnico, 09 de Mayo de 2008. 2 p.

7 SERNAGEOMIN. 2008e. Erupción del volcán Chaitén, Octavo Informe Técnico, 12 de Mayo de 2008. 4 p.

8 SERNAGEOMIN. 2008f. Erupción del volcán Chaitén, Décimo Segundo Informe Técnico, 21 de Mayo de 2008: 4 p.
} 
altitudes of about 7-10 km. Small PDCs were observed advancing down the east flank (SERNAGEOMIN, 2008c). A third episode of vigorous explosive activity occurred on 8 May, with an eruption column reaching an altitude of 20-22 km (Carn et al., 2009). By this time, the two vents through the dome had merged into a single vent approximately $0.8 \mathrm{~km}$ in diameter (Basualto et al., 2008). After 8 May, explosive activity began to wane for the last time (Fig. 3c). By 12 May sustained column heights were only about 4-5 km, and the volcano entered a transitional phase from explosive to effusive activity (Pallister et al., 2013, this volume).
Seismicity at the volcano was not adequately monitored until after the start of the eruption. Late on 30 April (local time) local residents began feeling earthquakes (Castro and Dingwell, 2009), and the Chilean Servicio Nacional de Geología y Minería (SERNAGEOMIN) began detecting volcano-tectonic (VT) earthquakes in the region. Over the next 30 hours approximately 15 major VT earthquakes were detected (Basualto et al., 2008). On 1 May, seismometers detected a M3.5 earthquake (Table 1) that was located about $15 \mathrm{~km}$ north of Chaitén town, which may have signaled the onset of the eruption; 5 hours later minor ashfall was observed in town.

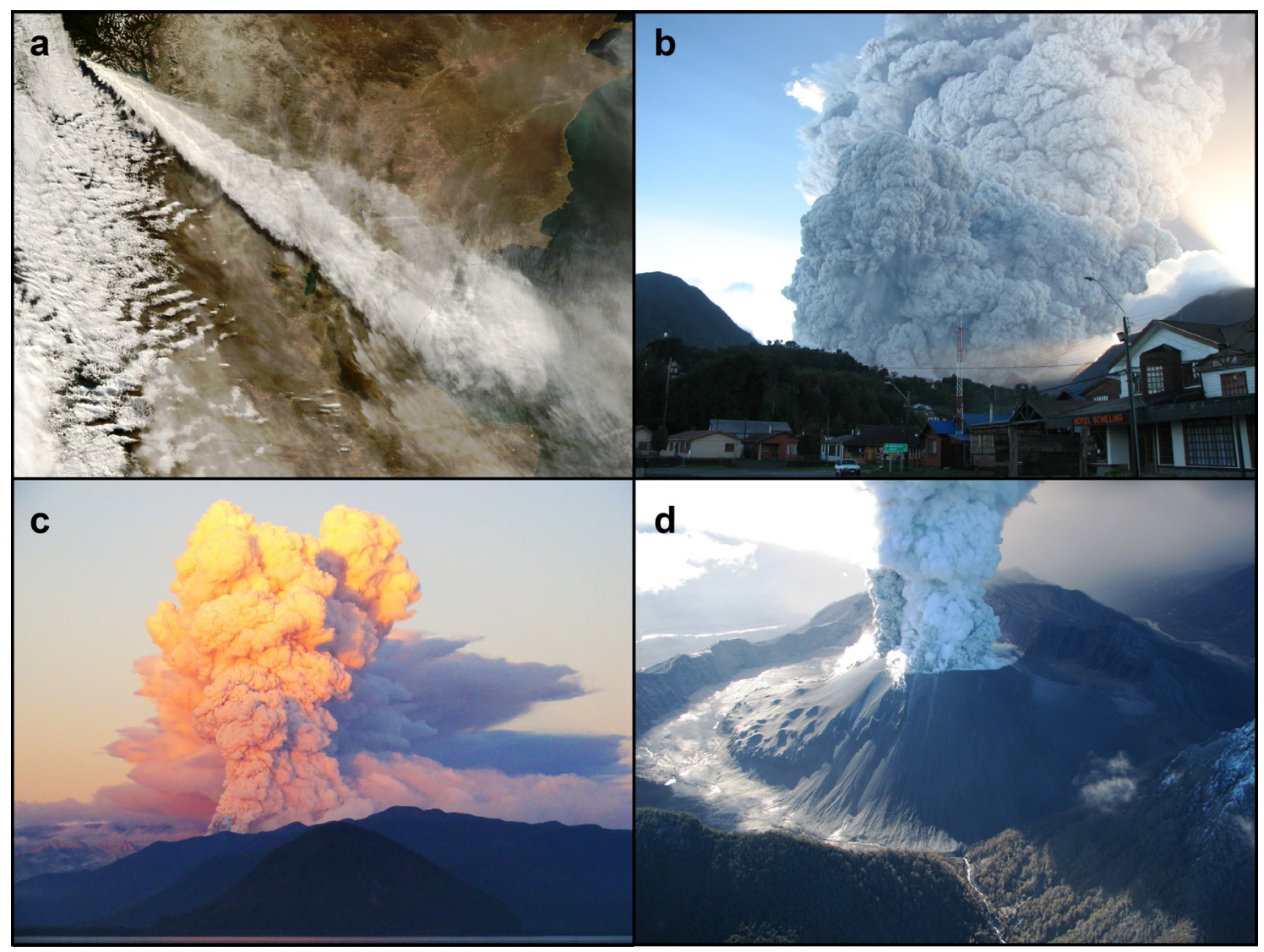

FIG. 3. Images of explosive phase of eruption of Chaitén Volcano. a. Moderate Resolution Imaging Spectroradiometer (MODIS) image captured from NASA's Terra satellite shows eruption plume dispersed across Argentina and the Atlantic Ocean. The visible plume is about $700 \mathrm{~km}$ long. NASA MODIS Rapid Response Team, 3 May 2008, 14:35 UTC; b. View of climactic eruption on 6 May 2008 looking north from Chaitén town. Photograph by D. Basualto, SERNAGEOMIN; c. Oblique aerial photograph of eruption plume on 10 May 2008. Plume height is approximately 4-5 km above sea level. View is looking east from Gulf of Corcovado. Photograph by D. Basualto, SERNAGEOMIN; d. View of Chaitén lava dome looking north on 26 May 2008. Note simultaneous explosion and effusion of new lava on left-central side of dome. Caldera is about $3 \mathrm{~km}$ wide. See Pallister et al. (2013, this volume) for details. Photograph by Jeff Marso, United States Geological Survey. 
On 3 May SERNAGEOMIN installed a seismic network around Chaitén Volcano (Basualto et al., 2008). Between 4 and 12 May, the network detected persistent VT earthquakes, about 70 events per day having an average maximum magnitude $\sim$ M3.5. Following the last vigorous Plinian explosion on 8 May, seismicity declined notably to about 20 VT events per day having maximum magnitude $\sim \mathrm{M} 3$.

\subsection{Effusive phase}

As explosive activity waned, effusive activity began. From 8 to 12 May, the predominance of lowmagnitude ( $\leq$ M2.5) VT earthquakes transitioned to hybrid and long-period low-frequency earthquakes, which in hindsight suggest the onset of lava effusion during this period (Basualto et al., 2008). Owing to inclement weather, newly effusing lava was not confirmed visually until 21 May (SERNAGEOMIN, 2008f). A transitional phase of the eruption, which included simultaneous explosion and effusion, lasted from about 8 to 12 May until the end of the month (Pallister et al., 2013, this volume) (Fig. 3d).

The effusive phase of eruption can be segregated into three distinct phases (Pallister et al., 2013, this volume): a dominantly exogenous growth phase; a phase of simultaneous spine extrusion and endogenous growth; and a dominantly endogenous growth phase. The exogenous phase, which lasted from early June through September 2008, produced multiple lava lobes that buried much of the pre-2008 lava dome (Fig. 4). Approximately $0.5 \mathrm{~km}^{3}$ of rhyolite lava was erupted at an average rate of $45 \mathrm{~m}^{3} \mathrm{~s}^{-1}$ during this four-month period (Pallister et al., 2013, this volume). Spine extrusion began in October 2008 and continued until mid-February 2009, accompanied by localized endogenous growth. Between June 2008 and mid-February 2009 , collapses from the lava dome produced rockfalls and minor PDCs within the caldera and two major PDCs that entered the Chaitén River valley through a breach in the south caldera wall (Major et al., 2013, this volume). After a substantial dome collapse on 19 February 2009, which produced the largest PDC in the Chaitén River valley (Fig. 5), the eruption entered a renewed and dominantly endogenous phase of dome growth that lasted until late 2009 or possibly earliest 2010 (Pallister et al., 2013, this volume). Seismicity during the period of lava effusion was dominated by hybrid earthquakes having magnitudes ranging from $\mathrm{M}<2$ to $\sim \mathrm{M} 4$ (Basualto et al., 2008).

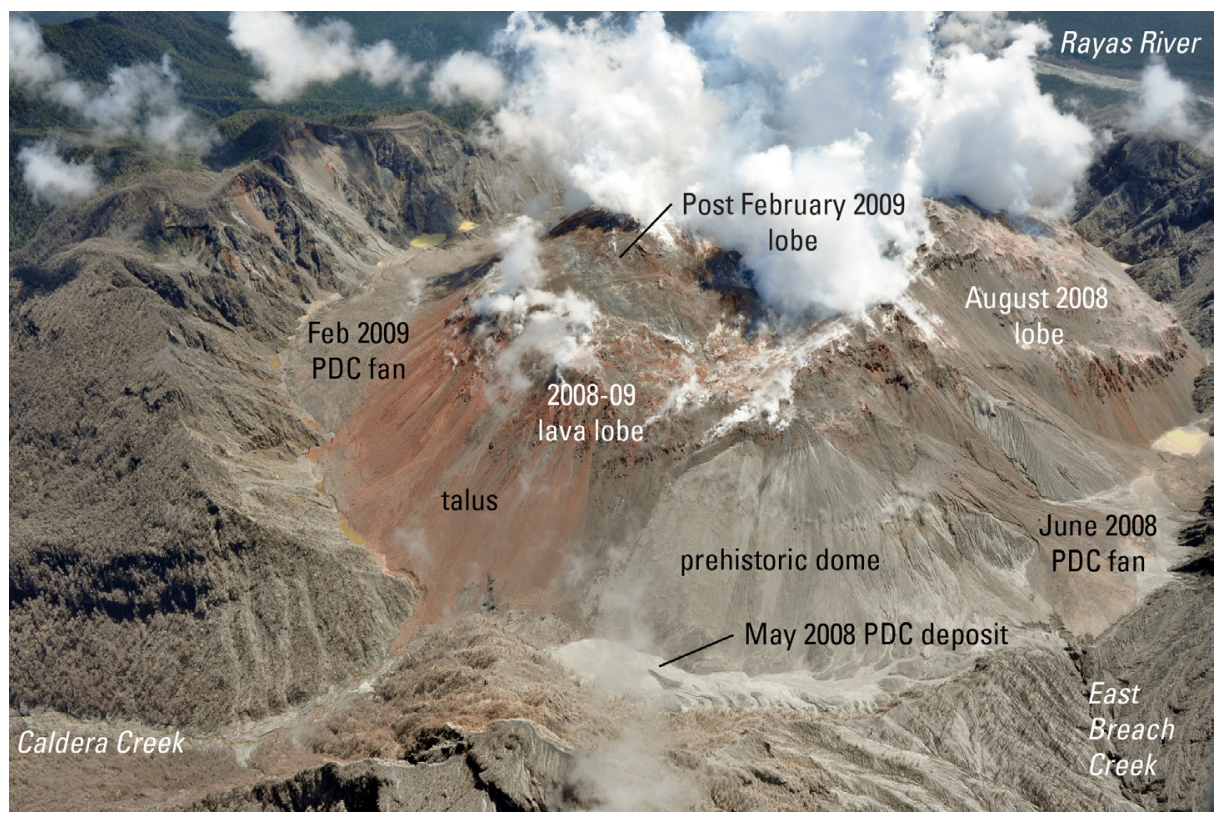

FIG. 4. Oblique aerial photograph of Chaitén lava dome. Various lava lobes and pyroclastic-density-current deposits are noted. Caldera is about $3 \mathrm{~km}$ wide. See Pallister et al. (2013, this volume) for details. Photograph by John Pallister, United States Geological Survey, 24 January 2010. 


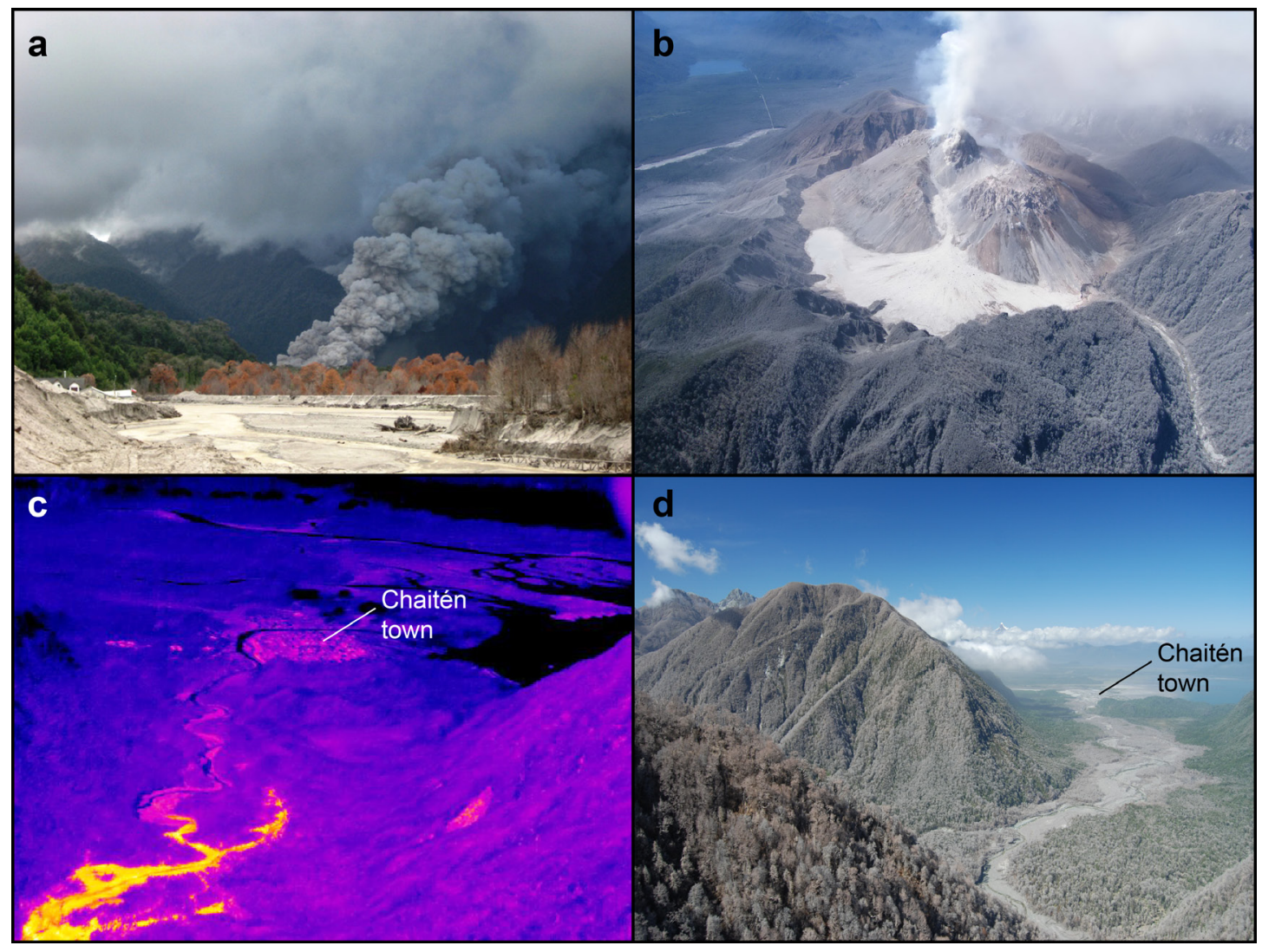

FIG. 5. Images of 19 February 2009 pyroclastic density current (PDC) and extent of deposit in caldera and Chaitén River valley. a. PDC flowing into Chaitén River valley following collapse of the lava dome. Image of the PDC's lofting ash cloud taken from bridge in Chaitén town at 10:43 a.m. local time. Image courtesy of Dagoberto Guzman, Parque Pumalín. Published with permission; b. Aerial view of PDC deposit in western sector of caldera. Photograph by P. Duhart, SERNAGEOMIN, 24 February 2009; c. Oblique aerial thermal image looking downstream along Chaitén River valley taken on 25 February 2009 from middle reach of Chaitén valley. Note the still hot distal end of the 19 February 2009 PDC deposit. Chaitén town in the distance is $10 \mathrm{~km}$ downstream from the caldera center. Image courtesy of A. Pavez, Departamento de Geofísica, Universidad de Chile; d. Oblique aerial view looking downstream along Chaitén River valley from near caldera rim. Note extent of 19 February 2009 PDC deposit along river channel. Dead forest along river floodplain is caused mostly by post-emplacement flooding and reworking of deposit. Chaitén town is in the background. Photograph taken 24 January 2010.

\section{Broad impacts of the 2008 explosive eruptive phase}

The explosive phase of the eruption and PDCs associated with subsequent dome collapses caused considerable damage to proximal forest vegetation (Fig. 6), affected commercial airline traffic, and disrupted daily life in downwind communities (e.g., Wilson et al., 2009a, b; Pallister et al., 2010; Swanson et al., 2013, this volume). Close to the volcano, approximately $480 \mathrm{~km}^{2}$ of forest were heavily damaged (Swanson et al., 2013, this volume). PDCs associated with the explosive phase of the eruption leveled patches of forest north and northeast of the volcano, a rain of coarse lapilli-rich tephra stripped foliage and limbs from trees along plume trajectories out to tens of $\mathrm{km}$ distance, and thick deposits of fine tephra in forest canopy caused branch breakage on large trees and bowing of small trees (Pallister et al., 2010; Swanson et al., 2013, this volume) (Figs. 6, 7). Extensive tracts of forest were damaged (Fig. 7D) by a delayed, but physiologically uncertain cause related to fine-grained tephra fall and possibly to release of volcanic gases (Lowenstern et al., 2012; Swanson et al. (2013, this volume) in the weeks to months following the explosive phase of eruption. 


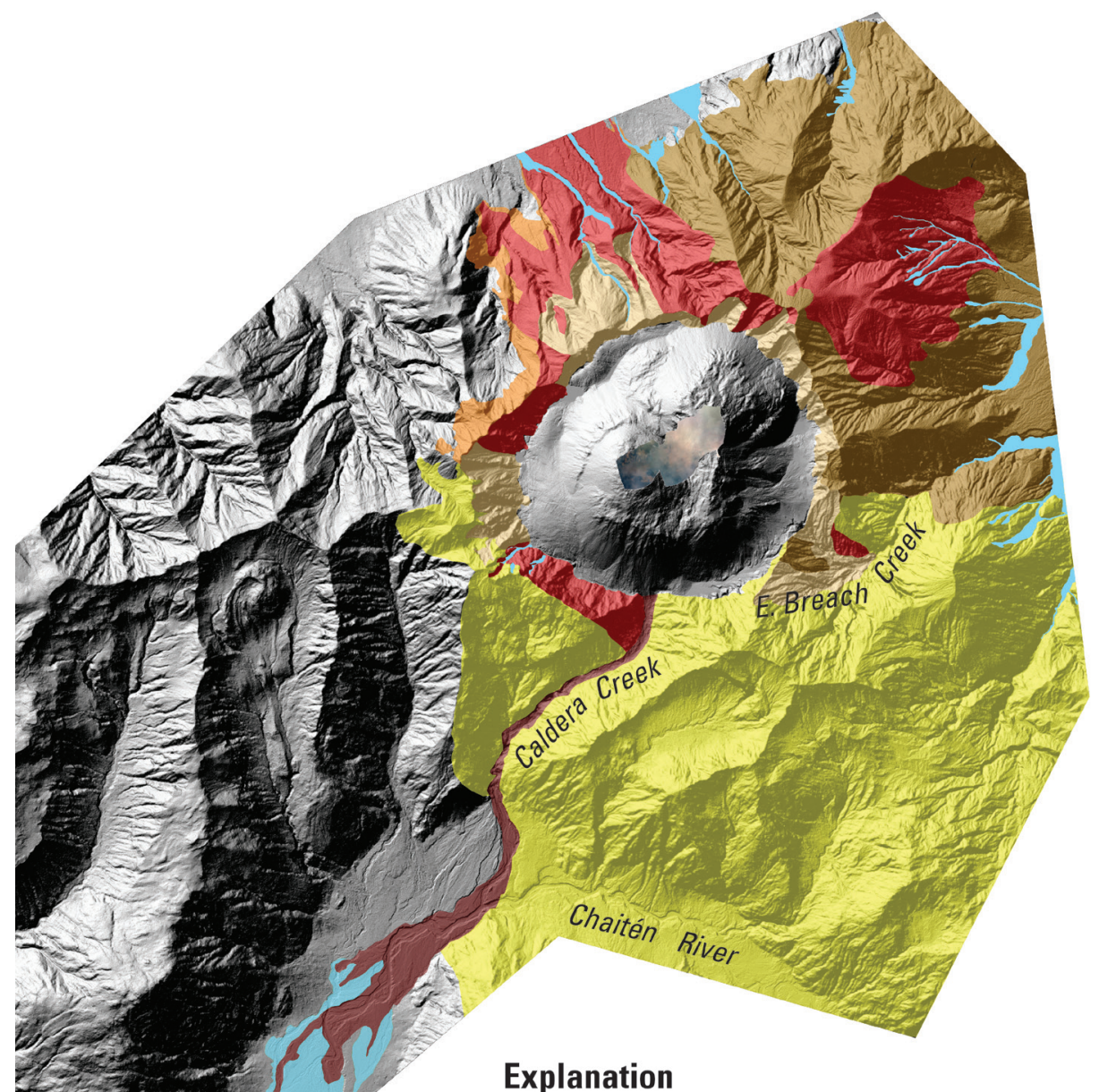

\section{Explanation}

Trees largely removed

Dominantly felled trees

Singed trees with canopy intact

Standing trees with canopy removed

Standing trees with canopy partially intact or foliage damaged

February 2009 PDC deposit

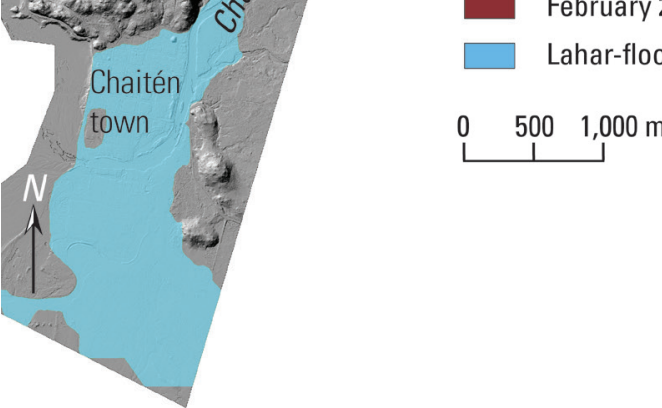

FIG. 6. Photo-interpretation of forest damage zones at Chaitén Volcano superposed on a lidar-derived digital elevation model. See Major et al. (2013, this volume) and Swanson et al. (2013, this volume) for details. Base map from SERNAGEOMIN has 1-m resolution and uses UTM Zone 18 South projection. The horizontal datum is WGS84. 


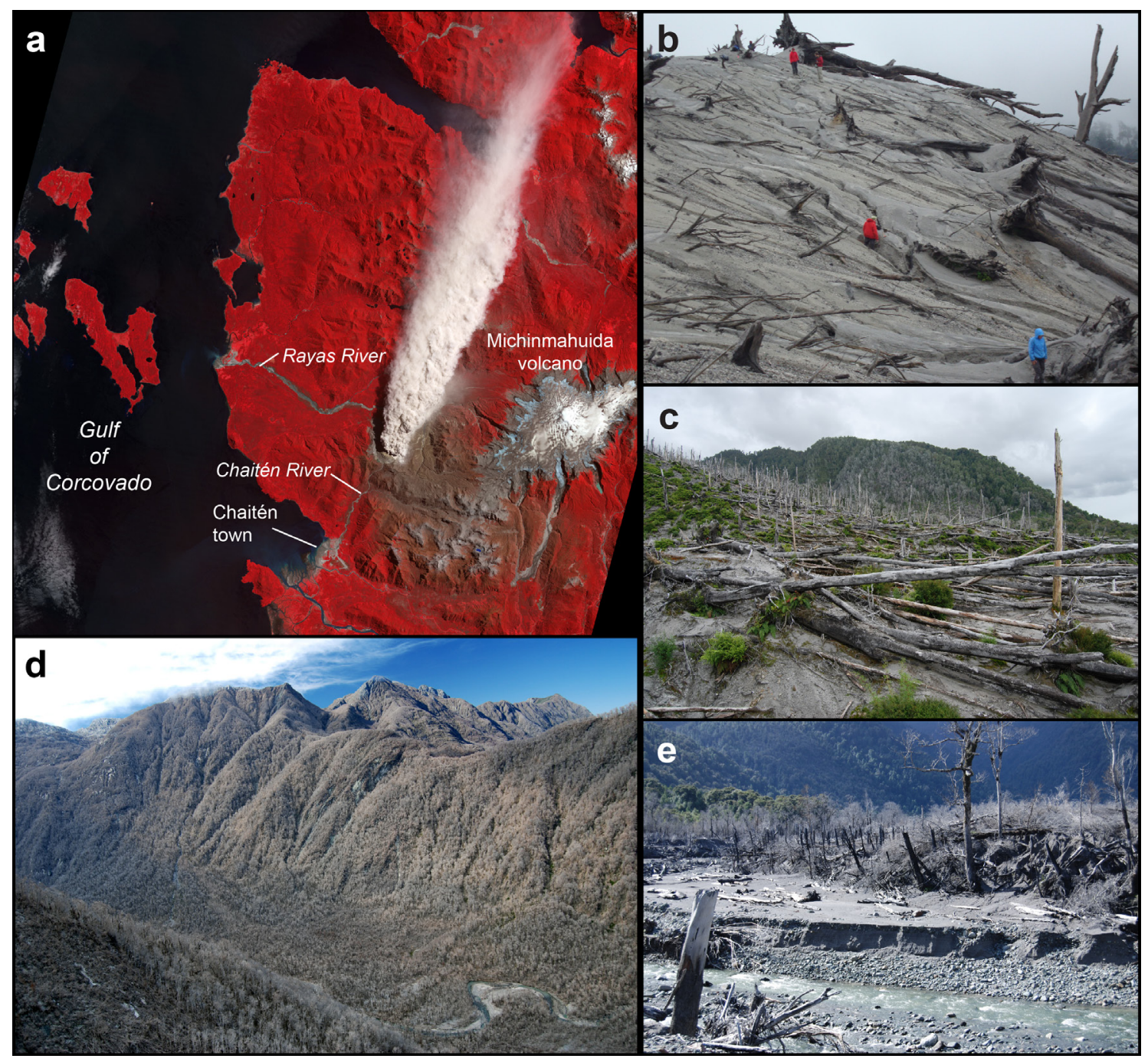

FIG. 7. Images of forest damage at Chaitén Volcano. a. False-color Advanced Spaceborne Thermal Emmisson and Reflection Radiometer (ASTER) image (image 2009019) obtained by NASA's Terra satellite on 19 January 2009. Red color indicates green vegetation. Note the extensive forest damage (brown shades) east and southeast of the volcano caused by fine-grained tephra fall and possibly by released magmatic chlorine; b. Forest damage at north rim of caldera caused by blast-like pyroclastic density current. See Major et al. (2013, this volume) and Swanson et al. (2013, this volume) for details. Photograph by Fred Swanson, United States Forest Service, 21 January 2011; c. Trees toppled by blast-like pyroclastic density current on north flank of volcano. See Major et al. (2013, this volume) for details. Photograph taken 19 January 2011; d. Photograph of extensive tract of damaged forest in upper Chaitén River valley. Photograph taken 23 January 2010. See Swanson et al. (2013, this volume) for details; e. Forest damage caused by burial by hot pyroclastic-density-current deposit in Chaitén River valley. See Major et al. (2013, this volume) for details. Photograph taken 5 March 2012.

Strikingly minor rainfalls in the days following extensive tephra deposition led to rapid runoff and tephra remobilization, which caused swift and abundant sediment loading of proximal river systems (Pierson et al., 2013) (Fig. 8). That sediment loading led to rapid aggradation of the Chaitén River channel, overbank flooding, river avulsion, and severe damage to the town of Chaitén (Pierson et al., 2013) (Fig. 9). Flushing of sediment from the Rayas, Chaitén, and Negro Rivers to the sea affected local aquaculture, and formed a pair of deltas at the former and new mouths of the Chaitén River (Fig. 2). Burial of the 


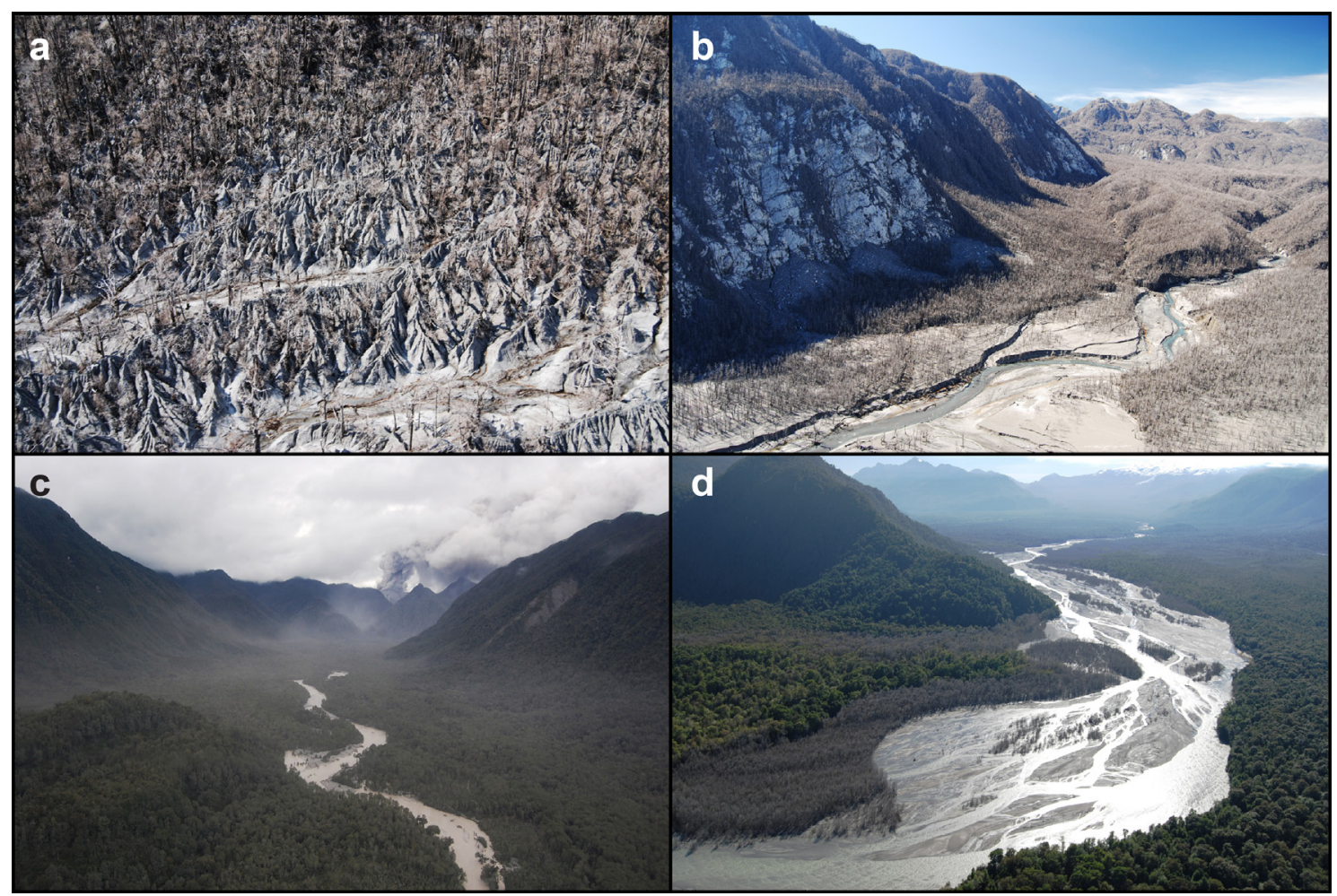

FIG. 8. Images of tephra erosion and sediment loading of rivers around Chaitén. a. Extensive erosion of tephra fall from drainage divide between Chaitén River and East River (see fig. 2 for geographic locations); b. Sediment loading along lower reach of East River. Terrace fill is at least $10 \mathrm{~m}$ thick; c. Sediment loading along Chaitén River valley following modest rainfall within days of waning of the main explosive phase of the eruption. Valley fill is about $7 \mathrm{~m}$ thick. See Pierson et al. (2013) for details. Photograph by J. Muñoz, SERNAGEOMIN, 24 May 2008; d. Oblique aerial view looking upstream of sediment loading on Rayas River. Fill is several m thick. Photographs a, b, and d taken 23 January 2010.

Chaitén airport in sediment and impingement of the Chaitén ferry dock by rapid delta growth seriously affected the two main modes of transportation to this region. As of 2013, small debris flows and floods from tephra- and PDC-affected tributary channels have continued to wash out local roads and disrupt regional ground travel.

Extensive downwind tephra fall in Chile and Argentina (Watt et al., 2009) broadly affected infrastructure, agriculture, and population. Electrical distribution networks suffered damage directly from tephra deposition and from tree fall associated with tephra deposition, municipal surface-water supplies were subjected to increased turbidity levels, and ground transportation networks suffered disruption owing to reduced visibility (Wilson et al., 2009a). Minor disruptions to telecommunication devices occurred as a result of ash penetration. Substantial pasture and cropland downwind were coated with
$<1 \mathrm{~mm}$ to as much as $10 \mathrm{~mm}$ of fine tephra fall (Watt et al., 2009) leading to crop and livestock loss; ingestion of ash by livestock led to fungal infections and tooth wear (Wilson et al., 2009b). Studies of downwind environmental impacts show that the tephra fall released a number of volatile trace elements to the environment that resulted in significant, but ephemeral, compositional changes in the biogeochemistry of soil, biota, and lakes in the region (Martin et al., 2009; Ruggieri et al., 2012). Concentrations of several volatile trace elements (B, Cd, Zn, Tl, Cu, Ni) were positively correlated with tephra fall thickness. However, owing to their ephemeral impacts, these changes posed little threat of environmental harm. Uptake of many of those elements by vegetation was short-lived. Martin et al. (2009) found that elevated element concentrations in coirón grass (Festuca pallenscens) persisted for $<8$ months. Of greater concern was the potential 


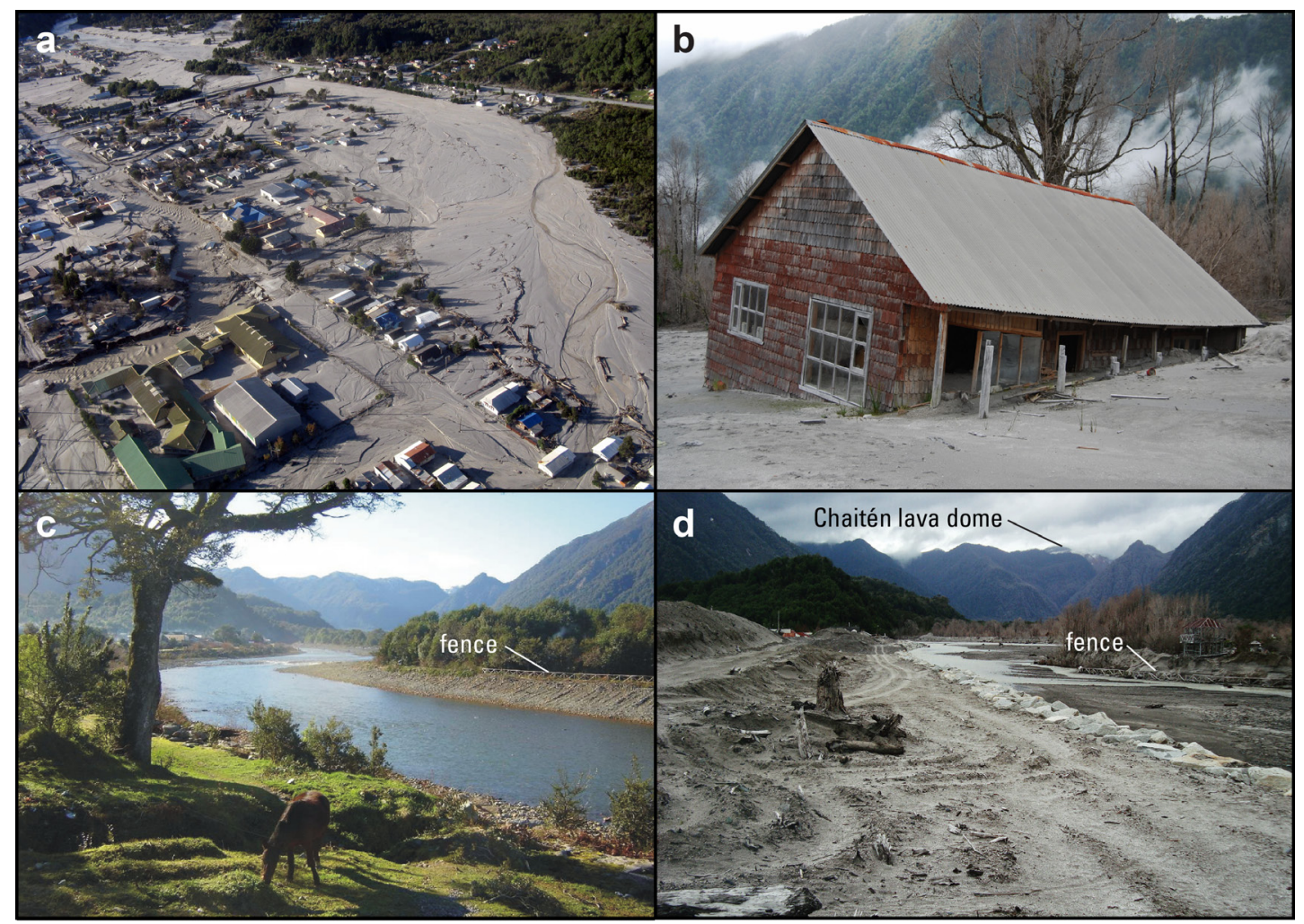

FIG. 9. Images of damage caused by flooding and sediment aggradation in Chaitén town. a. Extensive sediment aggradation and avulsion of Chaitén River through town. Note the abandoned channel on right of image, and newly avulsed channel running through town on left of image. SERNAGEOMIN photograph, 26 May 2008; b. House deeply buried by sediment deposited overbank on terrace after Chaitén River channel filled with sediment. Photograph taken 22 January 2011; c. Preeruption view of Chaitén River looking upstream (north) from the Route 7 (national highway) bridge in the town. Note position of fence on terrace with respect to channel bed (Photograph (C) A. Alderete, 1 August 2007, used with permission); d. Posteruption view from same location. Note position of fence with respect to channel bed, and stump of tree pictured in preeruption view. The river eroded its left bank, and the main channel at this time passed east of the fenced land visible in photographs (Photograph (C) by H. Ulloa, Universidad Austral de Chile, 28 January 2010, used with permission).

environmental hazard posed by the thoracic $(<10 \mu \mathrm{m})$ and respirable $(<4 \mu \mathrm{m})$ fractions of extremely fine ash. Resuspension of the fine distal tephra fall by wind and especially vehicular activity caused persistent air quality problems (Martin et al., 2009). Even when traffic activity and wind speeds were low, concentrations of respirable particulates exceeded World Health Organization guidelines (Martin et al., 2009). The tephra also contained respirable crisobalite nanofibers, raising concerns about possible adverse health effects to long-term exposure (Reich et al., 2009; Horwell et al., 2010). Tephra from the initial eruption plume on 2 May also induced downwind cooling of the troposphere of up to $10^{\circ} \mathrm{K}$ (Wang et al., 2009).
The eruption of Chaitén posed a significant challenge for the emergency response system in Chile. Owing to the absence of a monitoring network at the volcano, an adequate eruption forecast was not possible at the time. An initial response to the eruption included rapid deployment of a seismic network around the volcano by SERNAGEOMIN scientists, supported in part by scientists from the United States Geological Survey-United States Agency for International Development Volcano Disaster Assistance Program. On the basis of a rapid hazards assessment by SERNAGEOMIN scientists, national authorities decided within days to evacuate the town of Chaitén. A full evacuation was complete by 6 May. Evacuation of the town spared injuries or fatalities from 
the rapid and extensive flooding that occurred less than a week later (Pierson et al., 2013) (Fig. 9). The eruption also motivated an unprecedented response by the national government in terms of long-term social support of the displaced community. A pilot study for the possible relocation of the town was ordered, which suggested a more secure settlement be established $30 \mathrm{~km}$ farther north. Chile's highest level of volcanic alert (red alert) was maintained for two years until May 2010 when eruptive activity had clearly ended. Following cessation of the eruption, the national government decided to allow limited resettlement of Chaitén town and many former inhabitants returned.

\section{Synopsis of scientific investigations}

The papers in this edition discuss the eruptive history of Chaitén Volcano and describe various aspects of the 2008-2009 eruption and its impacts. Three papers (Amigo et al., 2013, this volume; Lara et al., 2013, this volume; Watt et al., 2013, this volume) discuss new evidence and new analyses that show that Chaitén has been far more active during the Holocene than was previously thought. Watt et al. provide evidence for three substantial eruptions (not including the 2008-2009 eruption) in the past 5,000 years. On the basis of an estimated volume obtained from reconstructed isopachs, they conclude that the late Holocene rhyolite pumice that Naranjo and Stern (2004) attributed to an eruption of Michinmahuida Volcano is actually from the largest-volume Holocene eruption of Chaitén. Amigo et al. discuss new stratigraphic observations and new radiocarbon ages obtained from a suite of proximal outcrops which help constrain the record of large Holocene eruptions from Chaitén and Michinmahuida Volcanoes. They show that at least 11 Holocene eruptions have occurred between these two volcanoes, including three large Plinian eruptions and one ignimbriteforming eruption. In contrast to Watt et al. (2013, this volume), they conclude that the early Holocene eruption of Chaitén identified by Naranjo and Stern (2004) was the largest-volume eruption from this volcano. Lara et al. (2013, this volume) present evidence for a $17^{\text {th }}$ century eruption of Chaitén that produced impacts and deposits similar to those of the 2008-2009 eruption.

Aspects of the 2008-2009 eruption and its impacts are presented in six papers. Osores et al. (2013, this volume) present a refined analysis of initial efforts by Folch et al. (2008) to model tephra fall over Argentina using the model FALL3D. In their paper, Osores et al. (2013, this volume) demonstrate that refinement of key input parameters to the model greatly improves output fidelity, and that close international cooperation during future Andean eruptions could benefit real-time efforts at predicting plume trajectories, concentrations, and tephra-fall thicknesses. Pallister et al. (2013, this volume) provide a detailed analysis of the eruptive sequence and growth of the 20082009 lava dome. They classify the eruption into five distinct phases (explosive, transitional, exogenous lava flow, spine extrusion, endogenous growth) and show that the volcano effused a total of $0.8 \mathrm{~km}^{3}$ of rhyolite lava over a $\sim 18-20$-month period. Growth of the lava dome also occurred in phases. The effusion rate was most rapid over the first two weeks of dome growth $\left(66 \mathrm{~m}^{3} \mathrm{~s}^{-1}\right)$, averaged $45 \mathrm{~m}^{3} \mathrm{~s}^{-1}$ over the first four months, slowed to a negligible rate of growth by September 2008, then entered a renewed phase of growth that included a 5-month phase of spine extrusion and vigorous endogenous growth beginning in February 2009. Endogenous growth continued until latest 2009 or possibly earliest 2010. Such rapid effusion at Chaiten is among the greatest effusion rates documented during an historical dome-growth eruption. Thermal imagery obtained by Bernstein et al. (2013, this volume) shows that dome growth was at times simultaneously exogenous and endogenous, and that complex structures formed as lava extruded through multiple flow paths. PiñaGauthier et al. (2013, this volume) present data from a sparse GPS network deployed after the onset of eruption, and show that co-eruptive patterns of deflation and inflation correspond with variations in lava effusion rate.

Despite its magnitude, the Chaitén eruption generated only small PDCs having limited impact near the volcano. Major et al. (2013, this volume) show that the explosive activity and subsequent dome collapses during the effusive phase of eruption triggered small, moderate temperature $\left(<300^{\circ} \mathrm{C}\right) \mathrm{PDCs}$ that locally choked proximal channel reaches with thick sediment fill. A small-magnitude, blast-like PDC flowed north, and perhaps northeast, of the caldera, whereas larger block-and-ash-flow style PDCs related to dome collapses choked the middle to lower reaches of the Chaitén River valley south of the volcano. 
The eruption had varied ecological impacts, both immediate and delayed. Swanson et al. (2013, this volume) show that varied intensities of PDCs and thicknesses and size distributions of tephra fall created disturbance gradients across hundreds of square kilometers of native forest. Close to the vent, a blast-like PDC leveled a few square kilometers of mature forest, and a rain of lapilli-rich tephra locally stripped foliage and limbs from tree canopies. An unusual lapilli-rich lateral current, possibly caused by a downburst from a dense part of an eruption plume that had moved away from the volcano, caused local but extensive tree damage. Along the principal plume trajectories, thickly deposited $(>10 \mathrm{~cm})$ fine tephra loaded the forest canopy and caused extensive limb breakage and fall. For reasons yet unclear, a broad swath of forest affected only by fine tephra fall, but which retained its canopy, began to die off weeks to months after the explosive phase of the eruption ended. Despite broad ecological damage, the forest appears to be resilient. Even in the most severely disturbed areas, some surviving vegetation sprouted new foliage during the growing season following the eruption, although some of that new foliage died in succeeding years.

\section{New insights from the eruption}

The eruption of Chaitén Volcano sparked several additional studies beyond those included in this edition. Studies of tephra characteristics, magma degassing, and volcano deformation using InSAR at Chaitén provide constraints on magma fragmentation, release of magmatic elements, the physical nature of the magmatic system, and insights on the rapid onset of eruption. Castro and Dingwell (2009) show that the rhyolite magma remained exceptionally fluid and rose from depth greater than $5 \mathrm{~km}$ at velocities of about $0.5 \mathrm{~ms}^{-1}$. Textural characteristics of juvenile clasts from the climactic explosion on 6 May reveal that delayed vesicle formation allowed magma to maintain a low viscosity and supersaturation of volatiles until it had risen well up into the conduit (Alfano et al., 2012), and that magma vesiculation and fragmentation were triggered by sudden decompression associated with opening of the conduit. Lowenstern et al. (2012) show that degassing of $\mathrm{Cl}$ and other magmatic elements was caused by near-surface crystallization of the magma. From analyses of two pairs of InSAR images of Chaitén,
Wicks et al. (2011) determined that three separately deforming bodies were involved in the eruption of Chaitén. They show that the ultimate source of magma at Chaitén comes from an inclined sill (the reservoir) that feeds magma diagonally upward from a source at $20 \mathrm{~km}$ depth beneath Michinmahuida Volcano. Magma storage along this sill beneath Chaitén was controlled by existing faults related to the LOFZ (Fig. 1). Emanating from this sill was a near-vertical dike that extended toward the surface of Chaiten and fed the volcanic conduit. Rapid ascent of the rhyolite magma from storage along the sill resulted from vertical propagation of the dike beneath the volcano. The net decrease in volume of these three source bodies was about $10-30 \%$ of the estimated volume of erupted material (see below), which Wicks et al. (2011) concludes was an expected consequence of magma compressibility.

Initial estimates of the volume of erupted magma varied considerably owing to lack of data on proximal tephra thicknesses and poor estimates of volumes of effused lava. Study of the distribution of proximal tephra fall and refinement of bulk fall volume (Alfano et al., 2011) combined with a more comprehensive analysis of dome growth (Pallister et al., 2013, this volume) show that the total volume of magma erupted is about $0.9-1.1 \mathrm{~km}^{3}$ (dense rock equivalent). Those studies also show that the volume of erupted magma is partitioned roughly as $15-30 \%$ explosive product and $70-85 \%$ effusive product. Dispersed tephra falls of the explosive phase of eruption have an estimated bulk volume ranging from about $0.5-1.0 \mathrm{~km}^{3}$ (Alfano et al., 2011) which has a dense-rock-equivalent volume of about $0.15-0.3 \mathrm{~km}^{3}$ assuming a bulk tephra fall density of $800 \mathrm{~kg} / \mathrm{m}^{3}$. In contrast, the volume of lava effusion is estimated to be about $0.8 \mathrm{~km}^{3}$ (Pallister et al., 2013, this volume).

Secondary processes caused considerable damage during the Chaitén eruption. Proximal tephra fall was mobilized rapidly by the first rains that followed the main explosive phase of eruption. Pierson et al. (2013) show that a prolonged, complex and continuous 'lahar-flood' involving hyperconcentrated- and water-flow phases was triggered by a minor rainstorm on 11-12 May. Tephra mobilized by that rainstorm rapidly aggraded the Chaitén River channel (by 5 $\mathrm{m}$ within 24 hours and to $7 \mathrm{~m}$ within another 36 hours) as well as the Rayas, Negro, and Amarillo River channels, and prompted overbank flooding 
that buried much of the town of Chaitén in up to $3 \mathrm{~m}$ of sediment. Filling of the lower $3 \mathrm{~km}$ of the Chaitén River channel caused the river to avulse into the town, which caused considerable additional damage. Erosion of PDC deposits has contributed to sediment loads that have caused channel instability especially along the Chaitén River.

There are a number of topics that deserve further attention beyond those discussed in this edition. For example, the geology and Quaternary evolution of Chaitén Volcano still require detailed mapping and analysis; a study of the limited but interesting record of seismicity associated with the eruption could yield substantial insights about the geometry of the volcanic system; and additional petrological studies could address the mechanics of magma transport, the controls on the ratio of explosive to effusive products, and the transition from explosive to effusive behavior in greater detail. Studies of long-term geomorphological, ecological, and biological responses to the eruption will require an extended window of observation. The eruption challenged efficient operation of the national disaster response system, and has resulted in the creation of the so-called 'Red Nacional de Vigilancia Volcánica', a national volcanic response network. Implementation of this response network remains a challenge, especially regarding the interactions among various decision-making levels, but it is a positive step in dealing with the frequent volcanic eruptions in Chile which can have significant societal consequences.

\section{Acknowledgments}

The unexpected eruption of Chaitén Volcano caused significant economic and social disruption, yet provided an exceptional opportunity to learn about the causes and consequences of a relatively rare and small-volume rhyolite eruption. We offer sincere thanks to the authors with whom we have worked to produce the suite of papers contained in this edition, and to other authors whose work was unfortunately unable to be completed on time to be part of this volume. We thank the following reviewers, as well as those who have remained anonymous, for their time and effort in helping authors of this collection of papers craft their products: Á. Amigo, B. Brand, K. Bull, E. Calder, M. Coombs, D. Dzurisin, M. González, R. Hoblitt, M. Lisowski, J. Lowenstern, L. Mastin, J. Pallister, T. Pierson, C.B. Ramsey, M. Ramsey, H. Schwaiger, W. Scott, S. Self, L. Siebert, C. Stern, M. Suárez, J. Vallance, S. Watt, and R. Watts.

\section{References}

Alaback, P.B. 1991. Comparative ecology of temperate rainforests of the Americas along analogous climate gradients. Revista Chilena de Historia Natural 64: 399-412.

Alfano, F.; Bonadonna, C.; Volentik, A.C.M.; Connor, C.B.; Watt, S.F.L.; Pyle, D.M.; Connor, L.J. 2011. Tephra stratigraphy and eruptive volume of the May, 2008, Chaitén eruption, Chile. Bulletin of Volcanology 73 (5): 613-630.

Alfano, F.; Bonadonna, C.; Gurioli, L. 2012. Insights into eruption dynamics from textural analysis-the case of the May, 2008, Chaitén eruption. Bulletin of Volcanology 74 (9): 2095-2108. doi: 10.1007/s00445-012-0648-3.

Amigo, Á.; Lara, L.E.; Smith, V.C. 2013. Holocene record of large explosive eruptions from Chaitén and Michinmahuida Volcanoes, Chile. Andean Geology 40 (2): 227-248.

Barrientos, S.; Acevedo, P. 1992. Seismological aspects of the 1988-1989 Lonquimay (Chile) volcanic eruption. Journal of Volcanology and Geothermal Research 53: 73-87.

Basualto, D.; Peña, P.; Delgado, C.; Moreno, H.; Muñoz, J.O. 2008. Seismic activity related to the evolution of the explosive eruption of Chaitén Volcano in the Southern Andes Volcanic Zone. Eos, Transactions of the American Geophysical Union 89 (53), Fall Meeting Supplement, Abstract V43D-2178. San Francisco.

Bernstein, M.; Pavez, A.; Varley, N.; Whelley, P.; Calder, E. 2013. Rhyolite lava dome growth styles at Chaitén Volcano, Chile (2008-2010): Interpretation of thermal imagery. Andean Geology 40 (2): 295-309.

Cande, S.C.; Leslie, R.B. 1986. Late Cenezoic tectonics of the southern Chile trench. Journal of Geophysical Research 91 (B1): 471-496.

Carn, S.A.; Pallister, J.S.; Lara, L.; Ewert, J.W.; Watt, S.; Prata, A.J.; Thomas, R.J.; Villarosa, G. 2009. The unexpected awakening of Chaitén Volcano, Chile. Eos, Transactions of the American Geophysical Union 90 (24): 205-206.

Castro, J.M.; Dingwell, D.B. 2009. Rapid ascent of rhyolite magma at Chaitén Volcano, Chile. Nature 461: 780-783.

Cembrano, J.; Lara, L. 2009. The link between volcanism and tectonics in the southern volcanic zone of the Chilean Andes: a review. Tectonophysics 471: 96-113.

Durant, A.J.; Villarosa, G.; Rose, W.I.; Dellelle, P.; Prata, A.J.; Viramonte, J.G. 2012. Long-range volcanic ash transport and fallout during the 2008 eruption of 
Chaitén Volcano, Chile. Physics and Chemistry of the Earth 45-46: 50-64.

Dzierma, Y.; Wehrmann, H. 2012. On the likelihood of future eruptions in the Chilean Southern Volcanic Zone: interpreting the past century's eruption record based on statistical analyses. Andean Geology 39 (3): 380-393.

Folch, A.; Jorba, O.; Viramonte, J. 2008. Volcanic ash forecast: application to the May 2008 Chaitén eruption. Natural Hazards Earth System Science 8: 927-940.

Garreaud, R.D. 2009. The Andes climate and weather. Advances in Geosciences 22: 3-11.

Garreaud, R.; López, P.; Minvielle, M.; Rojas, M. 2013. Large-scale control on Patagonian climate. Journal of Climate 26 (1): 215-230.

Hildreth, W.; Fierstein, J. 2012. The Novarupta-Katmai eruption of 1912: largest eruption of the twentieth century; centennial perspectives. United States Geological Survey Professional Paper 1791: 259 p.

Horwell, C.J.; Le Blond, J.S.; Michnowicz, S.A.K.; Cressey, G. 2010. Cristobalite in a rhyolitic lava dome: evolution of ash hazard. Bulletin of Volcanology 72: 249-253.

Lara, L.E.; Amigo, A.; Orozco, G.; Silva, C. 2011a. Peligros Volcánicos de Chile. Servicio Nacional de Geología y Minería, Carta Geológica de Chile, Serie Geología Básica, 1 mapa escala 1:2.000.000.

Lara, L.E.; Orozco, G.; Piña-Gauthier, M. 2011b. 1835 AD fissure eruption at Osorno Volcano, Southern Andes: triggering by local intra-arc stress field instead of remote megathrust-related dynamic strain. Tectonophysics 530-531: 102-110.

Lara, L.E.; Moreno, R.; Amigo, Á.; Hoblitt, R.P.; Pierson, T.C. 2013. Late Holocene history of Chaitén Volcano: New evidence for a $17^{\text {th }}$ century eruption. Andean Geology 40 (2): 249-261.

López-Escobar, L.; Kilian, R.; Kempton, P.D.; Tagiri, M. 1993. Petrography and geochemistry of Quaternary rocks from the Southern Volcanic Zone of the Andes between $41^{\circ} 30^{\prime}$ and $46^{\circ} 00^{\prime} \mathrm{S}$, Chile. Revista Geológica de Chile 20 (1): 33-55.

Lowenstern, J.B.; Bleick, H.; Vazquez, J.A.; Castro, J.M.; Larson, P.B. 2012. Degassing of Cl, F, Li, and Be during extrusion and crystallization of the rhyolite dome at Volcán Chaitén, Chile during 2008 and 2009. Bulletin of Volcanology 74: 2303-2319.

Major, J.J.; Pierson, T.C.; Hoblitt, R.P.; Moreno, H. 2013. Pyroclastic density currents associated with the 2008-2009 eruption of Chaitén Volcano (Chile): Forest disturbances, deposits, and dynamics. Andean Geology 40 (2): 324-358.
Martin, R.S.; Watt, S.F.L.; Pyle, D.M.; Mather, T.A.; Matthews, N.E.; Georg, R.B.; Day, J.A.; Fairhead, T.; Witt, M.L.I.; Quayle, B.M. 2009. Environmental effects of ashfall in Argentina from the 2008 Chaitén volcanic eruption. Journal of Volcanology and Geothermal Research 184: 462-472.

Naranjo, J.A.; Stern, C.R. 2004. Holocene tephrochronology of the southernmost part $\left(42^{\circ} 30^{\prime}-45^{\circ} \mathrm{S}\right)$ of the Andean Southern Volcanic Zone. Revista Geológica de Chile 31 (2): 225-240.

Newhall, C.G.; Self, S. 1982. The volcanic explosivity index (VEI): an estimate of explosive magnitude for historical volcanism. Journal of Geophysical Research 87 (C2): 1231-1238.

Osores, M.S.; Folch, A.; Collini, E.; Villarosa, G.; Durant, A.; Pujol, G.; Viramonte, J.G. 2013. Validation of the FALL3D model for the 2008 Chaitén eruption using field and satellite data. Andean Geology 40 (2): 262-276.

Pallister, J.S.; Diefenbach, A.; Burton, W.; Muñoz, J.; Griswold, J.; Lara, L.; Lowenstern, J.; Valenzuela, C. 2013. The Chaitén rhyolite lava dome: Eruption sequence, lava dome volumes, rapid effusion rates and source of the rhyolite magma. Andean Geology 40 (2): 277-294.

Pallister, J.S.; Major, J.J.; Pierson, T.C.; Hoblitt, R.P.; Lowenstern, J.B.; Eichelberger, J.C.; Lara, L.; Moreno, H.; Muñoz, J.; Castro, J.M.; Iroumé, A.; Andreoli, A.; Jones, J.; Swanson, F.; Crisafulli, C. 2010. Interdisciplinary studies of eruption at Chaitén Volcano, Chile. Eos, Transactions of the American Geophysical Union 91 (42): 381-382.

Piña-Gauthier, M.; Lara, L.E.; Bataille, K.; Tassara, A.; Báez, J.C. 2013. Co-eruptive deformation and dome growth during the 2008-2009 Chaitén eruption, Southern Andes. Andean Geology 40 (2): 310-323.

Pierson, T.C.; Major, J.J.; Amigo, A.; Moreno, H. 2013. Acute sedimentation response to rainfall following the explosive phase of the 2008-2009 eruption of Chaitén Volcano, Chile. Bulletin of Volcanology 75, 723: 17 p. doi: 10.1007/s00445-013-0723-4.

Reich, M.; Zúñiga, A.; Amigo, A.; Vargas, G.; Morata, D.; Palacios, C.; Parada, M.A.; Garreaud, R.D. 2009. Formation of cristobalite nanofibers during explosive volcanic eruptions. Geology 37 (5): 435-438.

Ruggieri, F.; Fernández-Turiel, J.L.; Saavedra, J.; Gimeno, D.; Amigo, A.; Galindo, G.; Caselli, A. 2012. Contribution of volcanic ashes to the regional geochemical balance: the 2008 eruption of Chaitén Volcano, Southern Chile. Science of the Total Environment 425: 75-88. 
SERNAGEOMIN. 2002. Mapa Geológico de Chile. Servicio Nacional de Geología y Minería, Carta Geológica de Chile, Serie Geología Básica 75, 1 mapa en 3 hojas, escala 1:1.000.000. Santiago.

Siebert. L.; Simkin, T.; Kimberly, P. 2010. Volcanoes of the World, 3rd edition. Smithsonian Institution University of California Press: 551 p. Washington D.C. and Berkely, California.

Smith, R.B.; Evans, J.P. 2007. Orographic precipitation and water vapor fractionation over the Southern Andes. Journal of Hydrometeorology 8: 3-19.

Stern, C.R. 2004. Active Andean volcanism: its geologic and tectonic setting. Revista Geológica de Chile 31 (2): 161-206.

Stern, C.R.; Moreno, H.; López-Escobar, L.; Clavero, J.E.; Lara, L.E.; Naranjo, J.A.; Parada, M.A.; Skewes, M.A. 2007. Chilean Volcanoes. In The Geology of Chile (Moreno, T.; Gibbons, W.; editors). Geological Society of London: 149-180.

Stern, C.R.; Cruz, I.; Caracotche S.; Charlin, J. 2012. Grey porphoritic obsidian from Chaitén Volcano found south of the Santa Cruz River in southernmost Patagonia. Magallania 40: 135-142.

Stern, C.R.; Narrova, X.; Muñoz, J. 2002. Obsidiana gris translúcida del volcán Chaitén en los sitios arqueológicos del Quilo (Isla Grande de Chiloé) y Chanchán (X Región), Chile, y obsidiana del Mioceno en Chiloé. Anales del Instituto de la Patagonia 30: 167-174.

Swanson, F.J.; Jones, J.A.; Crisafulli, C.; Lara, A. 2013. Effects of volcanic and hydrologic processes on forest vegetation, Chaitén Volcano, Chile. Andean Geology 40 (2): 359-391.

Thomason, L.W.; Pitts, M.C. 2008. CALIPSO observations of volcanic aerosol in the stratosphere. In Lidar Remote Sensing for Environmental Monitoring IX (Upendra, N.S.; Kazuhiro, A.; Achuthan, J.; editors). Society of Photo-Optical Instrumentation Engineers: 71530O-71530O-8. Bellingham, Washington. doi: 10.1117/12.804090.

Wang, K.; Hu, Y.; Bevis, M.; Kendrick, E.; Smalley Jr., R.; Barriga Vargas, R.; Lauría, E. 2007. Crustal motion in the zone of the 1960 Chile earthquake: Detangling earthquake-cycle deformation and forearc-sliver translation. Geochemistry, Geophysics, Geosystems 8 (Q10010). doi: 10.1029/2007GC001721.

Wang, K.; Hu, Y.; Bevis, M.; Kendrick, E.; Smalley Jr., R.; Barriga Vargas, R.; Lauría, E. 2008. Correction to 'Crustal motion in the zone of the 1960 Chile earthquake: Detangling earthquake-cycle deformation and forearc-sliver translation'. Geochemistry, Geophysics, Geosystems 9 (Q04017). doi: 10.1029/2007GC001869.

Wang, K-Y.; Lin, S-C.; Lee, L-C. 2009. Immediate impact of the Mt. Chaitén eruption on atmosphere from FORMOSAT-3/COSMIC constellation. Geophysical Research Letters 36 (L03808). doi: 10.1029/2008GL036802:

Watt, S.F.L.; Pyle, D.M.; Mather, T.A. 2013. Evidence of mid- to late-Holocene explosive rhyolitic eruptions from Chaitén Volcano, Chile. Andean Geology 40 (2): 216-226.

Watt, S.F.L.; Pyle, D.M.; Mather, T.A.; Martin, R.S.; Matthews, N.E. 2009. Fallout and distribution of volcanic ash over Argentina following the May 2008 explosive eruption of Chaitén, Chile. Journal of Geophysical Research 114 (B04207). doi: 10.1029/2008JB006219.

Wicks, C.; de la Llera, J.C.; Lara, L.E.; Lowenstern, J. 2011. The role of dyking and fault control in the rapid onset of eruption at Chaitén Volcano, Chile. Nature 478: 374-377.

Wilson, T.M.; Leonard, G.S.; Stewart, C.; Villarosa, G.; Rovere, E.I.; Baxter, P.J.; Johnston, D.; Cronin, S.J. 2009a. Impacts on critical infrastructure following the May 2008 Chaitén eruption in Patagonia. Geological Society of America, Abstracts with Programs 41 (7): 431. Portland, Oregon.

Wilson, T.M.; Leonard, G.S.; Stewart, C.; Baxter, P.J.; Villarosa, G.; Rovere, E.I.; Johnston, D.; Cronin, S.J. 2009b. Impacts on agriculture following the May 2008 Chaitén eruption in Patagonia. Geological Society of America Abstracts with Programs 41 (7): 493. Portland, Oregon.

Manuscript received: January 24, 2013; revised/accepted: April 05, 2013; available online: April 09, 2013. 